Hydrol. Earth Syst. Sci., 13, 2003-2021, 2009

www.hydrol-earth-syst-sci.net/13/2003/2009/

(C) Author(s) 2009. This work is distributed under

the Creative Commons Attribution 3.0 License.

\title{
Modelling water-harvesting systems in the arid south of Tunisia using SWAT
}

\author{
M. Ouessar ${ }^{1}$, A. Bruggeman ${ }^{2}$, F. Abdelli ${ }^{1}$, R. H. Mohtar ${ }^{3}$, D. Gabriels ${ }^{4}$, and W. M. Cornelis ${ }^{4}$ \\ ${ }^{1}$ Institut des Régions Arides (IRA), Route de Jorf, 4119 Medenine, Tunisia \\ ${ }^{2}$ International Center for Agricultural Research in the Dry Areas (ICARDA), P.O. Box 5466, Aleppo, Syria \\ ${ }^{3}$ Department of Agricultural and Biological Engineering, Purdue University, West Lafayette, IN 47907, USA \\ ${ }^{4}$ Department of Soil Management - International Centre for Eremology, Ghent University, Coupure links 653, \\ 9000 Ghent, Belgium
}

Received: 10 March 2008 - Published in Hydrol. Earth Syst. Sci. Discuss.: 9 July 2008

Revised: 30 April 2009 - Accepted: 29 September 2009 - Published: 29 October 2009

\begin{abstract}
In many arid countries, runoff water-harvesting systems support the livelihood of the rural population. Little is known, however, about the effect of these systems on the water balance components of arid watersheds. The objective of this study was to adapt and evaluate the GIS-based watershed model SWAT (Soil Water Assessment Tool) for simulating the main hydrologic processes in arid environments. The model was applied to the $270-\mathrm{km}^{2}$ watershed of wadi Koutine in southeast Tunisia, which receives about $200 \mathrm{~mm}$ annual rain. The main adjustment for adapting the model to this dry Mediterranean environment was the inclusion of waterharvesting systems, which capture and use surface runoff for crop production in upstream subbasins, and a modification of the crop growth processes. The adjusted version of the model was named SWAT-WH. Model evaluation was performed based on 38 runoff events recorded at the Koutine station between 1973 and 1985 . The model predicted that the average annual watershed rainfall of the 12-year evaluation period $(209 \mathrm{~mm})$ was split into ET $(72 \%)$, groundwater recharge (22\%) and outflow (6\%). The evaluation coefficients for calibration and validation were, respectively, $R^{2}$ (coefficient of determination) 0.77 and $0.44 ; E$ (NashSutcliffe coefficient) 0.73 and 0.43; and MAE (Mean Absolute Error) $2.6 \mathrm{~mm}$ and $3.0 \mathrm{~mm}$, indicating that the model could reproduce the observed events reasonably well. However, the runoff record was dominated by two extreme events, which had a strong effect on the evaluation criteria. Discrepancies remained mainly due to uncertainties in the ob-
\end{abstract}

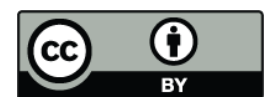

Correspondence to: M. Ouessar (med.ouessar@ira.agrinet.tn ) served daily rainfall and runoff data. Recommendations for future research include the installation of additional rainfall and runoff gauges with continuous data logging and the collection of more field data to represent the soils and land use. In addition, crop growth and yield monitoring is needed for a proper evaluation of crop production, to allow an economic assessment of the different water uses in the watershed.

\section{Introduction}

Water management is the most critical issue in dry areas as it impacts the livelihood of people and the productivity of the land and the society in general. For thousands of years, inhabitants of the dry areas have constructed waterharvesting systems that helped them cope with water scarcity (El Amami, 1984; Boers, 1994; Oweis et al., 2004). These systems were built to capture surface runoff from sparsely covered, rocky mountain slopes or to divert occasional wadi flow to fields for crop production. Despite the long and successful history of these systems, little is known about their effect on the hydrological processes in these dry areas.

Southeast Tunisia provides a typical example of the intensive management of scarce water resources in southern Mediterranean drylands. In this region, communities traditionally constructed earthen dikes with small spillways across the wadis to harvest the surface runoff from the surrounding degraded mountain slopes in the upstream areas. The soil that built up behind the dike formed a terrace that is used for cropping. These ancient water-harvesting systems are referred to as jessour. Water harvesting gradually also expanded to the foothills of the mountains, especially during

Published by Copernicus Publications on behalf of the European Geosciences Union. 
the last three decades. Here earthen dikes were made in the gently sloping plains to harvest the runoff from the adjacent mountain slopes. These so-called tabias are often built in sequence, with spillways to distribute the water evenly among them. Thus, these water-harvesting systems intercept surface runoff from adjacent land units for crop production (mainly drought-tolerant olive trees) on broad terraces in upstream catchments, while this water would have flowed downstream through the wadi otherwise.

Over time researchers have tried to obtain a better understanding of the water resources and their uses in this water scarce environment. Between 1973 and 1985 a runoff station was established at the outlet of the $272-\mathrm{km}^{2}$ Koutine watershed. During this relatively wet period, the 209-mm average annual rainfall over the watershed produced an average runoff of $12 \mathrm{~mm} / \mathrm{yr}$ ( $6 \%$ of the rain), which flooded the downstream rangelands in the coastal plain (sebkhas) (Fersi, 1985). The runoff water improved the productivity of these lands, which are the traditional grazing grounds of camels, sheep and goats. However, in dry years (e.g., 1981/1982), no runoff reached the downstream areas.

Transmission losses of the runoff that flows through the wide wadi bed are serving as a source of recharge for the region's aquifers. The magnitude of groundwater recharge was assessed by Derouiche (1997). She computed the recharge of the $725-\mathrm{km}^{2}$ Zeuss-Koutine aquifer, which underlays most of the wadi Koutine watershed, using biannual and annual groundwater level observations in 28 piezometers and boreholes and the finite difference groundwater flow model MULTIC (Djebbi, 1992). Lateral inflow from the upstream aquifer in the south (Grès de Trias) (301/s) and direct recharge in the Matmata mountains (41/s) were assumed constant and were estimated by calibration, whereas recharge from the remainder of the soils was assumed negligible. For the period $1974 / 75$ to $1984 / 85$, average annual groundwater recharge from wadis and the Matmata mountains (upper boundary of the model) was computed to be equal to $301 \mathrm{l} / \mathrm{s}$. This would be equal to $13.1 \mathrm{~mm}$ over the area of the aquifer and $6 \%$ of the average annual rainfall for this period in the wadi Koutine watershed.

The above two studies indicated that approximately $88 \%$ of the rain that falls on the watershed ends up as evapotranspiration. However, the evapotranspiration process is not equally beneficial over the watershed. Whereas the lush olive tree cover on the water-harvesting units indicates a productive use of the water, evaporation losses from the degraded, sparsely covered soils of the rangelands are high.

Local authorities have requested researchers to provide them with better information to help them understand the effectiveness of different support measures on the distribution of the water in these dryland watersheds for competing up- and downstream uses and users: (i) mainly rainfall and surface runoff for olive production and rangelands and (ii) groundwater for domestic uses, agriculture, industries and tourism. Watershed models are key tools for providing in- sights into the distribution and uses of water over space and time and under different management practices. Although there are many watershed models (Singh and Woolhiser, 2002; Borah and Bera, 2004), few of them can be easily applied to simulate the highly spatially and temporally variable processes in arid watersheds. Furthermore, there is no model that can simulate the functioning of the water-harvesting systems in these arid watersheds, where runoff water from one land unit is captured for crop production by a downstream land unit inside the same subbasin, with excess runoff water flowing again further downstream.

The Soil and Water Assessment Tool (SWAT), developed by Arnold et al. (1998), was selected for the simulation of hydrological processes in arid watersheds with waterharvesting practices, because (1) it simulates all water flows, water balance components and crop yields of different land units at various temporal scales (daily and long-term); (2) it allows easy representation and use of spatially variable data, processes and results through a GIS interface; and (3) it has a wide development and users' community with open access to the model documentation and source code. Although a cell-based routing procedure, as opposed to SWAT's semidistributed approach at the subbasin level, would have been more suitable for modelling flows in arid environments, the above strengths were considered to outweigh this weakness.

Applications of SWAT in watersheds in humid regions have been abundantly published in the literature (e.g., Srinivasan et al., 1993; Srinivasan and Arnold, 1994; Cho et al., 1995; Bingner et al., 1997; Arnold et al., 1999; Santhi et al., 2001; Kaur et al., 2003). However, applications of SWAT in dry environments are still relatively limited. In Tunisia, Bouraoui et al. (2005) applied SWAT to an $8000-\mathrm{km}^{2}$ basin of the Medjerda river located in a semi-arid to sub-humid bioclimate (297-1056 mm annual rainfall) in the northwest of the country to study the potential hydrological and water quality (nitrate) impacts of land management scenarios. They found that the model was able to represent the hydrological cycle even though some discrepancies were observed, due to a lack of sufficient rainfall data but also due to the fact that reservoirs (dams) were not simulated. In Morocco, Chaponniere (2005) applied SWAT for the representation of the hydrological functioning of a semi-arid mountain watershed. She studied two theoretical scenarios on the potential effects of changing the partitioning between rainfall and snow on the outflow. She pointed out that one of the reasons for the poor functioning of the model was the fact that the local water-spreading systems (seguias), which have an important effect on the water routes inside the watershed, were not represented in the model. She recommended the integration of these systems for any further analysis of the water balance. Conan et al. (2003) applied SWAT (version 99.2) to demonstrate the impact of groundwater withdrawals on the hydrological behavior of the Upper Guadiana catchment located in a semi arid area $(400-500 \mathrm{~mm}$ rainfall) of central Spain. They found that although the model is well adapted to 
describing the changes from wetlands to drylands due to human interventions, it did not properly represent all the details of the discharge history. They recommended including additional rainfall data and reservoir operating information to enable better representation of the hydrological functioning of the watershed. To evaluate the effect of different land uses and management practices on surface and soil water flow in a small arid catchment in northern Syria, Bruggeman and Van der Meijden (2005) adapted SWAT by introducing a number of adjustments to the model including growth and dormancy of olives and winter crops, the effect of grazing on leaf area index (LAI), the change of Curve Number (CN) during the growing season, and the use of the "irrigation from reach" option to represent the runoff harvesting practices widely used in typical dry environments of North Africa and West Asia.

The overall objective of this paper is to adapt and evaluate SWAT for simulating the main hydrologic processes in arid Mediterranean environments. The specific objectives are to (i) develop a methodology to represent water-harvesting systems in SWAT; (ii) adjust the crop model parameters and processes to represent Mediterranean arid cropping systems; (iii) evaluate the new SWAT-WH version in a $270-\mathrm{km}^{2}$ dryland watershed in southeast Tunisia using 38 storm events; and iv) assess the magnitude of the water balance components (infiltration, percolation, transmission losses, outflow, and evapotranspiration) for different land uses.

\section{Materials and methods}

\subsection{Study area}

The study watershed, wadi Koutine, is located in the Jeffara region in southeast Tunisia. It lies in the upper arid bioclimate region (Floret and Pontanier, 1982). The rainfall regime is of Mediterranean type with the rainy season extending from September to April. The average annual rainfall ranges from $160 \mathrm{~mm}$ in Médenine (1900-2004) in the Jeffara plain to $235 \mathrm{~mm}$ at Béni Khédache (1969-2003) in the Matmata mountains. The average annual temperature is $20^{\circ} \mathrm{C}$, the coldest month is December (mean minimum daily temperature $7^{\circ} \mathrm{C}$ ) and the warmest month is July (mean maximum daily temperature $37^{\circ} \mathrm{C}$ ).

A runoff gauging station was established by the hydrological service of the Ministry of Agriculture (DGRE) in 1971 at the crossing point between wadi Koutine and the main road linking Médenine and Gabès (Fersi, 1985). The watershed upstream from the runoff station covers an area of $272 \mathrm{~km}^{2}$ and stretches from an elevation of $690 \mathrm{~m}$ above sea level (a.s.l.) in the Matmata mountains to $100 \mathrm{~m}$ a.s.l. at Koutine village and then extends downstream into the saline depression of Sebkha Oum Zessar before ending in the Mediterranean (Gulf of Gabès) (Fig. 1).
In addition to the presence of shallow aquifers (less than $50 \mathrm{~m}$ deep) as groundwater beneath the main wadis of the watershed (Hallouf, Nagab, Koutine), the study watershed covers partially the sandstone Triassic aquifer (Grès de Trias) (in the upstream part) and the Zeuss Koutine aquifer (in the middle and downstream parts). The first one provides the freshest groundwater of the region (salinity less than $1 \mathrm{~g} / \mathrm{l}$ ), which is mainly used for irrigation and drinking water salinity adjustment (mixing with more saline water), while the second one is the main source of water supply for the province of Médenine (Ouessar and Yahyaoui, 2006).

The land use of the study area is dominated by sparsely covered, degraded steppes. Cropped sites, mainly for growing olives, are found on terraces behind water-harvesting structures. Two types of water-harvesting techniques are practiced by the local farmers: jessour and tabias (Ouessar et al., 2006).

As described in the introduction, jessour are mainly found in the mountainous areas of the watershed. This ancient water-harvesting technique is widely spread in the region of the Matmata mountains. Jessour are constructed in the intermountain and hill water courses to intercept runoff and sediments. Jessour is the plural of a jessr which is a hydraulic unit made of three main components: a dike (locally called also tabia) in the form of a small earth embankment with a spillway made of stones, a terrace which represents the cropping area, and an impluvium which is the runoff catchment area (El Amami, 1984) (Fig. 2). The dikes are between 2 to $5 \mathrm{~m}$ high and have lengths between 15 to $50 \mathrm{~m}$ across the wadi (Ben Mechlia and Ouessar, 2004).

Tabias are essentially situated in the piedmont areas in the middle of the watershed on gentle slopes. The tabia is formed by a principal embankment of 50 to $150-\mathrm{m}$ situated along the contour with lateral bunds of about $30 \mathrm{~m}$ long at the ends. The tabia gains its water directly from its impluvium or by the diversion of wadi runoff. Water is captured until it reaches a height of 20 to $30 \mathrm{~cm}$, after which it is diverted (over flow), either by a spillway or at the upper ends of the lateral bunds (Alaya et al., 1993) (Fig. 2).

During rainfall events, the runoff that is generated at the level of the impluviums runs onto the terraces of the jessour and tabias. Part of the runoff water will form temporary ponds up to the level of the spillway. It will infiltrate into the soil slowly after the runoff event. The jessour cover the tributaries (talwegs), and receive runoff from the mountains (mountain rangeland). The tabias receive the runoff from their impluviums and/or the spillover from the upstream jessour if they are installed on the same tributary. The outflow from the jessour and tabias flows into the wadi.

\subsection{SWAT model}

SWAT is a physically-based continuous time model that operates on a daily time step to estimate the effects of land and water management and pollutant releases in stream systems 


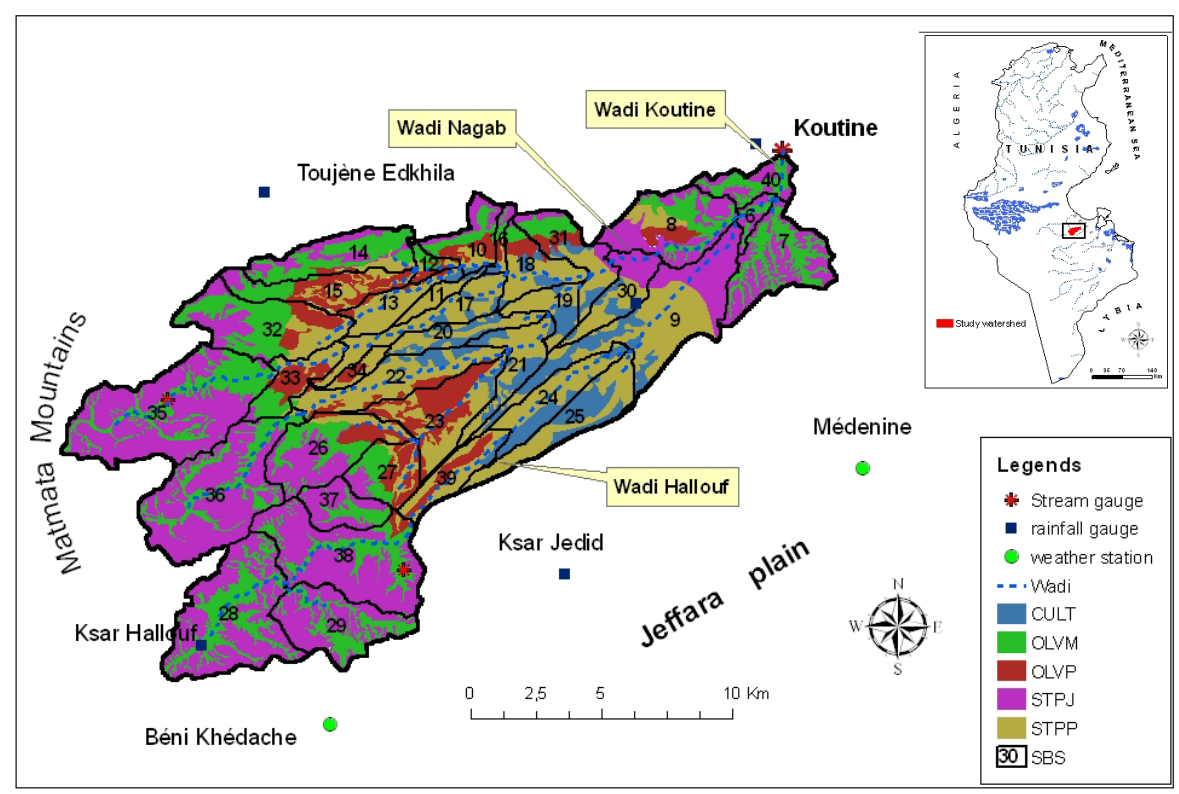

Fig. 1. Study watershed location and monitoring network (OLVM: Olives of the mountains (jessour); OLVP: Olives of plains (tabias); STPJ: Rangelands of the mountains; STPP: Rangelands of the plains; CULT: Cereals; SBS: Subbasin boundaries).

in large complex watersheds with varying soils, land use and management conditions over long periods of time (Neitsch et al., 2002). Spatial variability of soil, land use and management practices are accounted for by discretization of the watershed into subbasins based on the topography and stream network. Each subbasin consists of multiple Hydrologic Response Units (HRUs) representing unique combinations of soil and land cover properties.

The climatic variables consist of precipitation, maximum and minimum air temperature, solar radiation, wind speed, and relative humidity. SWAT includes also the WXGEN weather generator model (Sharpley and Williams, 1990) to generate climatic data or to fill in gaps in measured records. For this study, the weather generator was only used to fill in missing temperature data. The daily temperatures are generated by WXGEN from user-defined monthly means and standard deviations, using a weakly stationary process (Neitsch et al., 2002).

There are three options for estimating reference evapotranspiration (PET): Hargreaves (Hargreaves and Samani, 1985), Priestley-Taylor (Priestley and Taylor, 1972), and PenmanMonteith (Monteith, 1977; Allen, 1986). Considering the availability of data for the study area (minimum and maximum daily temperature), the PET was calculated by the Hargreaves method. Potential soil water evaporation is estimated as a function of PET and the plant's LAI and plant water transpiration is simulated as a linear function of PET and LAI.

SWAT provides two methods for estimating surface runoff volume: the SCS curve number procedure (SCS, 1972) and the Green and Ampt (1911) infiltration method. Because of the lack of long-term rainfall intensity data at the watershed level as required by the latter method, the SCS CN method was selected for runoff computation. It calculates the runoff for a given rainfall depth and $\mathrm{CN}$. It is an empirical formula based on several years of rainfall and runoff data obtained from a variety of combinations of soil, land use, topography and climate across the US. The $\mathrm{CN}$ is related to the land use and the soil hydrologic group. The method is widely used, not only in the US, but also in other countries (Ponce and Hawkins, 1996).

SWAT defines percolation as the water that drains through the root zone into the aquifer. Downward flow occurs when the field capacity of a soil layer is exceeded. The downward flow rate is governed by the saturated hydraulic conductivity $\left(K_{S}\right)$ of the soil layer. Lateral subsurface flow in the soil profile is calculated simultaneously with percolation. A kinematic storage routing method, which is based on slope, slope length, and saturated hydraulic conductivity is used to predict lateral flow in each soil layer. Lateral flow occurs when the storage in any layer exceeds field capacity and is a function of lateral flow travel time (days) and the difference between soil water content and field capacity (Neitsch et al., 2002).

The lateral flow and surface runoff of all HRUs are summed for each subbasin and then routed through the stream network. Transmission losses are computed as a function of the hydraulic conductivity of the channel bed $\left(K_{\text {chan }}\right)$, channel width and length, and flow duration, following the procedure of Lane (1983). SWAT routes the stream flow through the channel network using the variable storage routing method or the Muskingum river routing method. Both methods are variations of the kinematic wave model as detailed by Chow et al. (1988). 

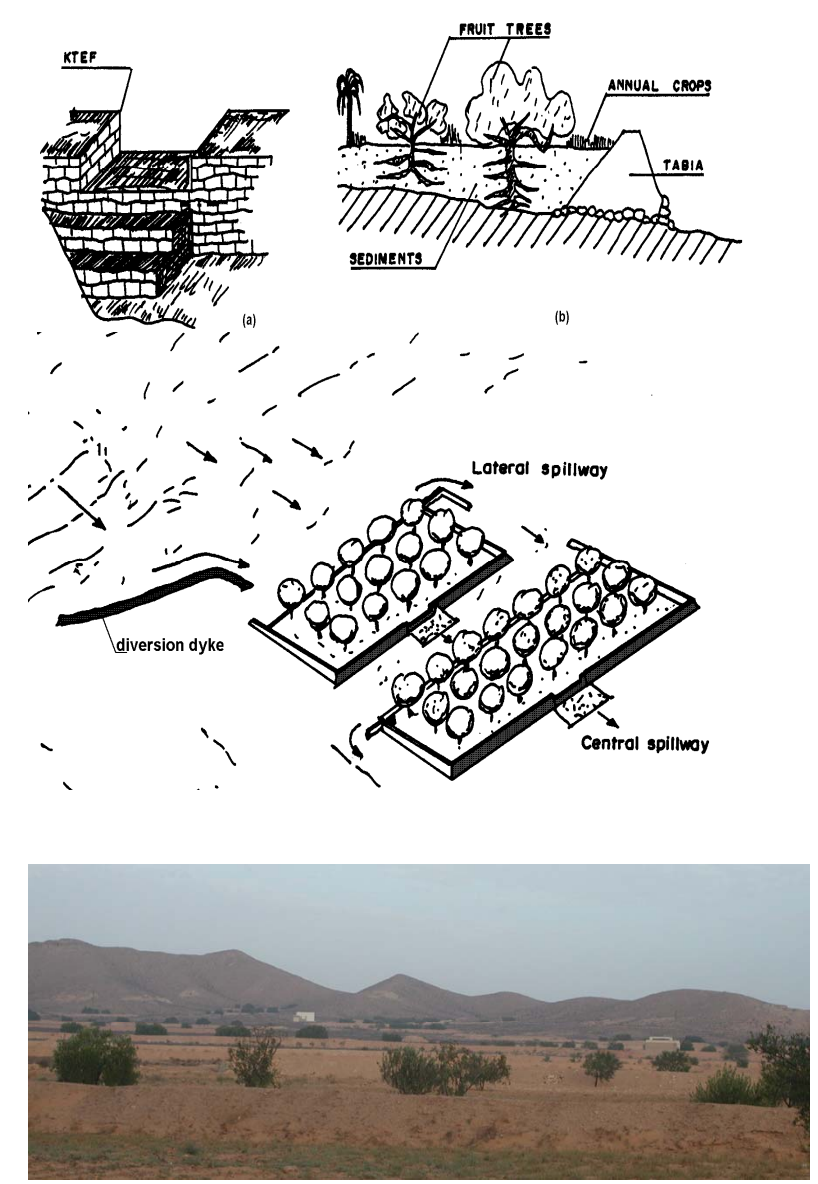

Fig. 2. Uppper: scheme of the Jessr components (a spillway, b side view) (adapted from El Amami, 1984). Lower: scheme of a tabia with natural impluvium (adapted from Alaya et al., 1993). In the photo: tabias are seen in the front (piedmont area) and jessour are found in the talwegs of the mountains in the back.

The crop growth and biomass production module uses a simplified form of the EPIC crop model (Williams et al., 1984). The model uses Monteith's approach to estimate the potential biomass accumulation (Monteith, 1977), coupled with water, temperature and nutrient stress adjustments. SWAT simulates also erosion and water quality processes but these are not considered in this application.

Considering the above processes, the water balance of the soils and streams of the watershed can be expressed as follows:

$\Delta S W=P-Q_{\mathrm{SURF}}+E T+W_{\mathrm{SEEP}}+Q_{G W}$

where $\Delta S W$ is the change in soil water content, $P$ is the precipitation, $Q_{\mathrm{SURF}}$ is the surface runoff out of the watershed, ET is the evapotranspiration, $W_{\text {SEEP }}$ is the percolation from the soil profile and $Q_{G W}$ represent the transmission losses from the streams. All parameters are expressed in $(\mathrm{mm})$ over the watershed area.

\subsection{Model modifications}

The main feature of jessour and tabias is that they receive runoff water generated by different HRUs (degraded, rocky rangelands) within the same subbasin. In SWAT, runoff is not routed between HRUs within the subbasin, but the runoff from all HRUs is added directly to the outlet of the subbasin. The SWAT code was modified to simulate the collection of runoff water behind the water-harvesting structures (jessour and tabias) by bringing the surface runoff and lateral flow generated in the subbasin back to the water-harvesting HRUs in the subbasin (Fig. 3).

SWAT's irrigation-from-reach option was used to allow the entry of input data for controlling the amount of water harvested by the different HRUs. Because the waterharvesting units may not be located in such a way that they capture all runoff that was generated within the subbasin, the parameter FLOWFR allows the user to specify the fraction of the runoff water that is harvested by the jessour and tabia HRUs. The maximum height of the water impoundment on each water-harvesting HRU is controlled by the height of the dikes and spillway and the slight surface slope of the land surface. This impoundment height is represented by the parameter DIVMAX, as illustrated in Fig. 4.

In subbasins with both water-harvesting systems, the jessour are generally located upstream from the tabias. Therefore, the runoff water is distributed to the jessour HRUs first and secondly to the tabia units. Finally, any excess will flow downstream and could be subjected to transmission losses in the main reach (wadi).

The water-harvesting process for the jessour HRUs in a subbasin is expressed by the following equations:

$$
D W=\frac{\operatorname{FLOWFR}(i) \times Q \mathrm{sub}}{10 \times \sum_{i=1}^{i=n} \operatorname{AREA}(\mathrm{i})}
$$

DWH(i) $=\operatorname{MIN}(D W, \operatorname{DIVMAX}(\mathrm{i}))$

$$
Q_{R E}=Q_{\mathrm{SUB}}-\sum_{i=1}^{i=n}(\mathrm{DWH}(\mathrm{i}) \times 10 \times \operatorname{AREA}(\mathrm{i}))
$$

where $D W$ is an intermediate parameter for the height of the harvested water on the water-harvesting HRU $(\mathrm{mm}), Q_{\text {SUB }}$ is the total runoff (surface runoff and lateral flow) generated in the subbasin $\left(\mathrm{m}^{3} / \mathrm{d}\right), i$ is the index for the jessour HRUs in the subbasin, $n$ is the total number of jessour HRUs in the subbasin, AREA(i) is the surface area of each jessour HRU (ha), DWH(i) is the final height of the harvested water on the jessour $\mathrm{HRU}(\mathrm{mm})$ and $Q_{R E}$ is the remaining runoff that will flow downstream $\left(\mathrm{m}^{3} / \mathrm{d}\right)$. The expression $\operatorname{MIN}(\mathrm{v} 1, \mathrm{v} 2)$ indicates that the minimum of the two values will be selected. It should be noted that within a subbasin the FLOWFR for all jessour HRUs will be constant. The same equations are also used for the tabia HRUs. As explained above, in the case 


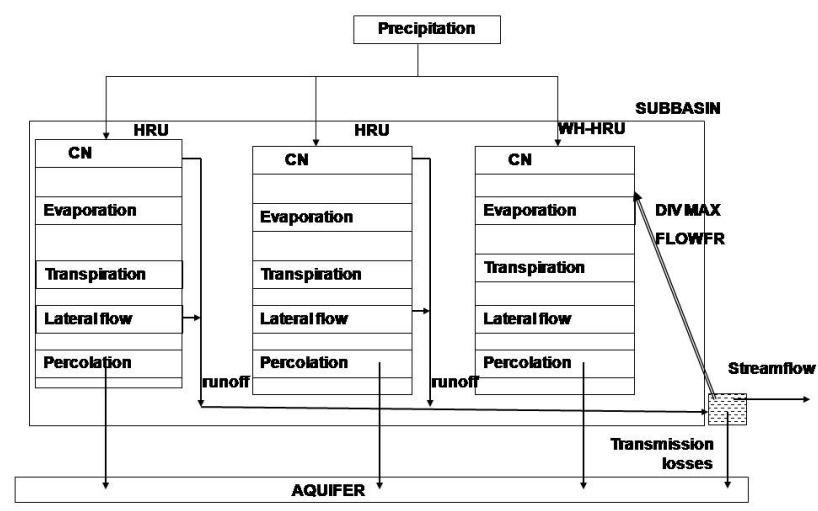

Fig. 3. SWAT water routing as applied in the study site (WH-HRU: water harvesting HRU, DIVMAX: maximum diversion (spillway height), FLOWFR: flow fraction).

of both jessour and tabias HRUs within the same subbasin, the equations are applied to the jessour first and then to the tabias with $Q_{\text {SUB }}$ set equal to $Q_{R E}$.

If the total water harvested by the HRU exceeds the field capacity of the soil profile, it will become percolation. This is different from the SWAT irrigation operation, which limits the water application to what can be stored in the soil profile. The lateral flow of the jessour and tabias was assumed zero (nearly level terraces). It is assumed that all harvested water infiltrates in the soil, so no open water evaporation losses are accounted for. This assumption seems reasonable, considering that generally only a few days ponding occur, during humid conditions with relatively low temperature and cloudy skies.

The second modification was the adjustment of the crop model parameters and processes to represent Mediterranean arid cropping systems. The initialization of the heat unit accumulation was changed to allow the perennials and annual crops to grow during the Mediterranean hydrologic year from fall to summer. The dormancy period was removed because the crops in the watershed do not become dormant. Furthermore, as olives are permanently green, the shedding of leaves for trees, present in the model, was removed. SWAT allows the user to specify a change in $\mathrm{CN}$ for selected tillage practices, but this option did not function in SWAT2000; this was corrected. The modified SWAT model is referred to as SWAT-WH.

\subsection{Model parameterization}

The new SWAT-WH was applied to the entire $272-\mathrm{km}^{2}$ large study watershed upstream from Koutine. We used a 12-year runoff record (1973/1974 till 1984/1985) available for the runoff station of Koutine (Fersi, 1985) for model testing and evaluation. The values of the base parameter set (reference scenario) are discussed in this section, the selection of parameters for calibration is explained in Sect. 2.5.

\subsubsection{Topography and watershed configuration}

A 30-m DEM was generated from available topographic maps of the area (scales of 1:50000; 1:100000 and 1:200 000), from a SPOT stereo pair and from the stream network digitized from a multi-spectral (XS) SPOT image, using the TOPOGRIDTOOL routine. The main channel network was created by the ArcView SWAT interface from the DEM, using a threshold upstream drainage area, which defines the head of a main channel, of 100 ha. Some of the generated stream channels were removed to match the actual occurrence of the streams as observed on the SPOT image. Especially in the upstream areas the channels are completely covered by cascades of jessour. A few subbasins were subdivided, through the manual addition of outlets, to ensure the connection between runoff generating areas and the different cropped areas that harvest this runoff. In this way 35 subbasins were obtained.

The main transmission losses are expected to take place at the level of the main reaches (wadis). A value of $70 \mathrm{~mm} / \mathrm{h}$, corresponding to the average effective hydraulic conductivity of a channel with sand and gravel and low silt content (Lane, 1983), was used. This value is also close to the average measured value $(91 \mathrm{~mm} / \mathrm{h})$ found by Osterkamp et al. (1995) in the United Arab Emirates for similar wadi bed properties as in the study watershed. The recharge from the wadis in the upstream subbasins that are completely covered with jessour, as well as from the tributaries in the subbasins, was assumed negligible $\left(K_{\text {chan }}=0 \mathrm{~mm} / \mathrm{h}\right)$.

\subsubsection{Climate}

Daily precipitation data are needed when using the SCS curve number method to model surface runoff. The daily rainfall data, recorded and published by the hydrological service of the Water Resources Directorate in the Ministry of Agriculture (DGRE, 1968-1985), were collected from the 7 stations (Koutine, Allamet, Toujène Edkhila, Ksar Hallouf, Ksar Jedid, Béni Khédache and Médenine) in and around the watershed (Fig. 1). SWAT allocates the nearest rain gauge to each subbasin. Due to some missing records, the rain gauge allocation is different for the first 3 years of the 12-year evaluation period. Values of maximum and minimum temperature were obtained from the weather stations of Médenine, Béni Khédache and El Fjè (IRA). The monthly average daily minimum and maximum temperatures and standard deviations of these stations were computed for use by the weather generator to fill in missing data.

\subsubsection{Soils}

Soil classes were obtained from the soil map (at 1:200 000 scale) of the Jeffara region produced by Taamallah (2003), based on a visual interpretation of a Spot multi-spectral (XS) image of 1998 and field investigations. Texture of 


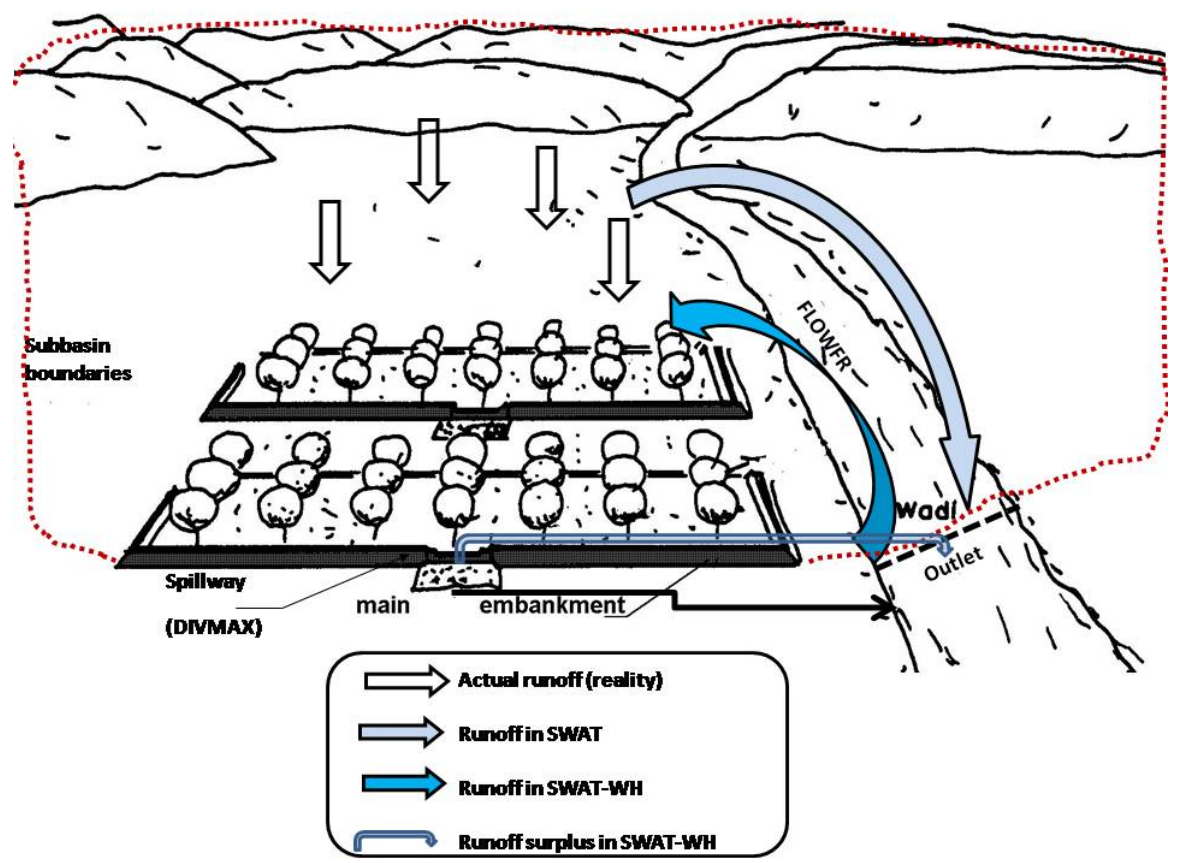

Fig. 4. Schematic representation of the runoff routing in SWAT and SWAT-WH. DIVMAX: spillway height, FLOWFR: flow fraction.

31 representative profiles was determined using the sievepipette method (Gee and Bauder, 1986) and organic matter by the method of Walkley and Black (1934).

The soil map was modified to take into account the soils built up behind the water-harvesting units as deposited sediments. The boundaries of the soil units were adjusted based on a supervised and unsupervised classification of the Spot XS image of 1991 and additional field investigations using a handheld Global Positioning System (GPS). Three classes were added: the deep "artificial" soils formed as small terraces behind the water-harvesting structures by the deposition of sediment (JESR: soils behind jessour, STAB: soils behind tabias) and the calcareous outcroppings on the mountains, as part of the Matmata cuesta, in the upstream parts of the watershed where the soil is almost nonexistent (AFFL).

For the soils on the terraces (JESR and STAB) of the water-harvesting structures, measured available water capacity (AWC), bulk density (BD) and saturated hydraulic conductivity $\left(K_{\text {soil }}\right)$ (Maati, 2001) were used. AWC was determined from the difference in soil-water content at $-33 \mathrm{kPa}$ and $-1500 \mathrm{kPa}$ using pressure chambers (Soil moisture Equipment, Santa Barbara CA, USA). The BD was measured using $100-\mathrm{cm}^{3}$ cores and $K_{\text {soil }}$ was obtained from infiltration experiments using a double ring with an inner diameter of $28 \mathrm{~cm}$ and an outer diameter of $53 \mathrm{~cm}$. As is frequently done in watershed modelling where the soil properties are not fully available (e.g., Heuvelmans et al., 2004; Bouraoui et al., 2005), the missing water characteristics of the remaining soils were derived by means of the calculator of Saxton (2005).
A summary of the soil characteristics is given in Table 1. It can be noted that the soils in the watershed are generally very shallow $(10-40 \mathrm{~cm})$, and have consequently limited water holding capacity except the fluvisols (PEAH), which are found in the northern, midstream part of the watershed, and the artificial soils created by the water-harvesting systems (JESR and STAB).

\subsubsection{Land use and $\mathrm{CN}$}

A land use map of the study area based on a semi-supervised classification of the Spot XS image of 1991 (Zerrim, 2004) was adjusted by adding the different soil and water management practices (jessour and tabias), with the help of a visual interpretation of the Spot XS image of 1998 and aerial photos (missions of 1975, 1990), in addition to field checks and GPS surveys.

The main land uses in the watershed are rangelands, fruit trees and cereals. Fruit trees, mainly olives, (Olea $\mathrm{Eu}$ ropaea), are found on the jessour and tabias only. Cereals (barley, Hordeum vulgare, and wheat, Triticum durum) are grown episodically during wet years. The natural vegetation (ranges) was divided into two classes: mountain and plain, because of their different phenology and grazing practices.

The soil hydrologic group and $\mathrm{CN}$ values were selected based on the SCS tables (SCS, 1986). Because of their shallowness, most soils were identified as group D soils, defined as soils with very low infiltration rates, including shallow soils over nearly impervious material (SCS, 1986). The rangelands were considered arid rangelands made of 
Table 1. Summary of the soil properties.

\begin{tabular}{lrrrrrrrr}
\hline Soil* & $\begin{array}{r}\text { Depth } \\
\mathrm{cm}\end{array}$ & $\begin{array}{r}\text { Clay } \\
\%\end{array}$ & $\begin{array}{r}\text { Silt } \\
\%\end{array}$ & $\begin{array}{r}\text { Sand } \\
\%\end{array}$ & $\begin{array}{r}\mathrm{BD} \\
\mathrm{mg} / \mathrm{m}^{3}\end{array}$ & $\begin{array}{r}\text { AWC } \\
\text { (vol) }\end{array}$ & $\begin{array}{r}\mathrm{K} \\
\mathrm{mm} / \mathrm{h}\end{array}$ & $\begin{array}{r}\text { OC } \\
\%\end{array}$ \\
\hline AFFL & $0-10$ & 13 & 12 & 75 & 1.5 & 12 & 18 & 0.24 \\
CRCG & $0-20$ & 10 & 9 & 81 & 1.6 & 10 & 29 & 0.28 \\
MBEH & $0-20$ & 13 & 11 & 75 & 1.5 & 12 & 18 & 0.24 \\
PEEH & $0-20$ & 11 & 11 & 78 & 1.6 & 12 & 24 & 0.29 \\
ISOH & $0-10$ & 7 & 4 & 89 & 1.7 & 9 & 53 & 0.22 \\
& $10-40$ & 9 & 7 & 84 & 1.6 & 10 & 37 & 0.18 \\
STAB & $0-7.5$ & 19 & 17 & 64 & 1.5 & 15 & 120 & 0.70 \\
& $7.5-100$ & 15 & 10 & 75 & 1.6 & 12 & 120 & 0.36 \\
PEAH & $0-70$ & 10 & 15 & 75 & 1.6 & 12 & 28 & 0.12 \\
& $70-140$ & 3 & 19 & 78 & 1.8 & 12 & 84 & 0.15 \\
& $140-200$ & 16 & 17 & 67 & 1.5 & 13 & 11 & 0.19 \\
JESR & $0-7.5$ & 15 & 21 & 64 & 1.4 & 18 & 60 & 1.02 \\
& $7.5-52.5$ & 17 & 19 & 64 & 1.5 & 18 & 60 & 0.51 \\
& $52.5-200$ & 14 & 14 & 72 & 1.7 & 14 & 17 & 0.28 \\
\hline
\end{tabular}

AWC: available water capacity; BD: bulk density; K: Hydraulic conductivity; OC: organic carbon.

AFFL: Outcropping; CRCG: calcimagnésiques sur rendzine calcalire (Rendzinas); ISOH: isohumiques bruns calcaires tronqués (Calcic Xerosols); JESR: soil on the terraces of jessour; MBEH: minéraux bruts d'érosion hydrique (Regosols); PEAH: Peu évolués d'apport hydrique (Fluvisols); PEEH: peu évolués d'érosion hydrique (Regosols); STAB: Soil on the terraces of tabias.

* - in French: French classification (CPCS, 1967) (Taamallah, 2003);

- between parentheses in English: FAO classification (FAO, 1989).

herbaceous-mixture of grass and low growing brush (SCS, 1986), while the cereals were considered small grains in straight rows and bare soils during fallow. The olives are grown on flat terraces, with a $\mathrm{CN}$ of 30 .

To allow a change in $\mathrm{CN}$ when the crops and rangelands have developed a protective ground cover, a tillage operation with zero depth and zero mixing was used. For the rangelands and cereals, the $\mathrm{CN}$ was set for three periods as a function of the growing cycles and management operations, and included planting, grazing, harvesting (Table 2).

\subsubsection{Crop growth and management parameters}

The crop parameters (potential heat units, base and optimal temperatures, length of the growing season, leaf area development parameters) for the relevant crops in the SWAT database were checked and adjusted to obtain the general growth and water use patterns as observed in the study area. Although, for this study, the testing of the crop input and output data focused on the effects of the soil water balance rather than on the actual crop yields, some adjustments were made as described below.

Olive trees are the dominant fruit trees cropped in the area. It was assumed that the olive trees have matured but kept growing normally by pruning the tree after harvest in December. The values of the radiation use efficiency and the harvest indices were adjusted to obtain biomass and yield production figures close to the average values found in the literature (Labras, 1996; Fleskens et al., 2005) and field knowledge.
The characteristics of the US southwest rangelands were used with minor adjustments (biomass production, grazing pattern, base and optimal growth temperature) based on research work undertaken in the arid regions of Tunisia (Floret and Pontanier, 1982; Neffati, 1994; Ouled Belgacem, 2006). The rangelands are generally grazed throughout the year by various animals like sheep, goat and camel.

After the first significant rains, which fall between October and November, the farmers plant barley and occasionally wheat and legumes. Following harvest in May, the stubble of cereals is completely grazed by the animals and only negligible amounts of residues are left. The cereal crop parameters suggested by Bruggeman and Van der Meijden (2005) for the Khanasser Valley (Syria) were adopted because of similar climatic dryland conditions.

As described previously, the water-harvesting systems are controlled by two parameters. The value of DIVMAX was set to $0.25 \mathrm{~m}$ for the jessour and $0.15 \mathrm{~m}$ for the tabias, based on field knowledge about average ponded water levels on the terraces of these water-harvesting systems (Chahbani, 1990; Alaya et al., 1993; Ben Mechlia and Ouessar, 2004). Considering that not all runoff water is captured by the waterharvesting systems, the FLOWFR of jessour and tabias were set to 0.90 and 0.95 , respectively. The jessour and tabias have similar characteristics throughout the watershed, so these values were assumed constant for all jessour and tabia HRUs. 
Table 2. Soil hydrological groups and base and final runoff curve number values, with the final values that were adjusted in the calibration to the right of the oblique.

\begin{tabular}{lrrrrrr}
\hline Landuse $^{1}$ & Soil $^{2}$ & Area $(\%)^{3}$ & HYDGRP $^{4}$ & \multicolumn{3}{c}{ Curve Number } \\
\hline \multicolumn{1}{l}{ Mountain rangelands } & & & Oct-Nov & Dec-Jun & Jul-Sep \\
\hline STPJ & AFFL & 4.4 & D & 97 & 97 & 97 \\
STPJ & CRCG & 0.8 & D & $93 / 95$ & $89 / 91$ & 97 \\
STPJ & MBEH & 26.3 & D & $93 / 95$ & $89 / 91$ & 97 \\
STPJ & ISOH & 3.9 & D & $93 / 86$ & $89 / 84$ & $97 / 95$ \\
STPJ & PEAH & 0.1 & A & $80 / 63$ & $71 / 55$ & $84 / 77$ \\
\hline Plain rangelands & & & Oct-Nov & Dec-Jun & Jul-Sep \\
\hline STPP & CRCG & 9.5 & D & $93 / 92$ & 89 & 97 \\
STPP & MBEH & 0.2 & D & $93 / 92$ & 89 & 97 \\
STPP & PEEH & 3.9 & D & $93 / 92$ & 89 & 97 \\
STPP & ISOH & 6.9 & D & $93 / 86$ & $89 / 84$ & $97 / 94$ \\
STPP & PEAH & 5.5 & A & $80 / 61$ & $71 / 55$ & $84 / 77$ \\
\hline Cereals & & & Nov-Dec & Jan-Apr & May-Oct \\
\hline CULT & CRCG & 3.6 & D & 91 & $89 / 88$ & 94 \\
CULT & PEEH & 0.1 & D & 91 & $89 / 88$ & 94 \\
CULT & ISOH & 3.4 & D & 91 & $89 / 84$ & $94 / 91$ \\
CULT & PEAH & 0.8 & A & $72 / 63$ & $67 / 60$ & 77 \\
\hline Olives & & & & & Jan-Dec & \\
\hline OLVM & JESR & 22 & A & 30 & & \\
OLVP & STAB & 8.6 & & & & \\
\hline
\end{tabular}

${ }^{1}$ CULT: Cereals; OLVM: Olives of the mountains (jessour); OLVP: Olives of plains (tabias); STPJ: Rangelands of the mountains; STPP: Rangelands of the plains.

2 AFFL: Outcropping; CRCG: calcimagnésiques sur rendzine calcalire (Rendzinas); ISOH: isohumiques bruns calcaires tronqués (Calcic Xerosols); JESR: soil on the terraces of jessour; MBEH: minéraux bruts d'érosion hydrique (Regosols); PEAH: Peu évolués d'apport hydrique (Fluvisols); PEEH: peu évolués d'érosion hydrique (Regosols); STAB: Soil on the terraces of tabias.

3 As percentage of the watershed total area.

${ }^{4}$ Hydrologic group as defined by SCS (1986); A: deep, well-drained, sandy soils with high infiltration rates; B: moderately deep to deep, moderately fine to moderately coarse textured soils with moderate infiltration rates; D: shallow soils with very low infiltration rates.

${ }^{5}$ For rangelands in the study area (O. Belgacem, personal communication, 2004):

- March-June: 25-50\% cover,

- October-November: 10-25\% cover,

- July-September: $<10 \%$ cover.

\subsection{Model evaluation}

\subsubsection{Sensitivity analysis}

A parameter sensitivity analysis was conducted to evaluate the effect of changes in the baseline model parameter values, as presented in the previous section, on the water balance components and to identify which parameters have the most effect on the outflow of Koutine watershed. The parameters selected in this study for sensitivity analysis were based on the model description and other published SWAT applications. In a study on the long term land use effects in the semi-arid Upper Guadiana river basin (Spain), Conan et al. (2003) found that the water yield in the stream is sensitive to $\mathrm{CN}, \mathrm{AWC}, K_{\text {soil }}$, and aquifer properties. As far as surface runoff is concerned and according to various authors (e.g. Heuvelmans et al., 2004; Chu and Shirmohammadi, 2004), the most sensitive parameters in SWAT are CN, AWC, $K_{\text {soil }}$ and $K_{\text {chan. }}$. For our specific case, we added DIVMAX and FLOWFR which are the parameters used to represent the water-harvesting systems. Thus, a total of six input parameters were evaluated.

For each model run, one parameter was changed. Because of the linear nature of this type of analysis, no parameter 
interaction is captured. The relative sensitivity index (RSI) (Lenhart et al., 2002) was computed as follows:

$\mathrm{RSI}=\frac{\left(y_{1}-y_{0}\right) / y_{0}}{\left(x_{1}-x_{0}\right) / x_{0}}$

where $x_{0}$ is the initial value of the parameter (baseline parameters) and $y_{0}$ is the corresponding output, $x_{1}$ is the tested value of the parameter and $y_{1}$ is the corresponding output. The sign of the index shows if the model reacts codirectionally to the input parameter change, i.e. if an increase of the parameter generates an increase of the output and vice versa. A value of RSI near zero indicates that the output is not sensitive to the parameter under study, whereas a value of RSI significantly different from zero shows high degree of sensitivity Lenhart et al. (2002) classified the RSI sensitivity values as follows: less than 0.05 : small to negligible; 0.05-0.2: medium; 0.2-1.0: high; more than 1: very high.

The tested values of the parameters were their expected upper and lower limits. Based on field knowledge, the DIVMAX was changed up and down by $20 \%$ while the FLOWFR was varied by $5 \%$. The soils in the watershed are dominated by sandy loam textures, which have an expected AWC range of 6 to $12 \%$ (e.g., Allen et al., 1998). However, because the total storage capacity of the soils is also affected by their depth, which involves another uncertainty, this parameter was varied with a 50\% range. The changes for the $K_{\text {soil }}$ were similar. For the $K_{\text {chan }}$, we used the range given by Lane (1983) and Osterkamp et al. (1995) (30 to $180 \mathrm{~mm} / \mathrm{h}$ ) for typical dry channels. The range for the $\mathrm{CN}$ was $5 \%$ up and $10 \%$ down. Because the $\mathrm{CN}$ values in the watershed are relatively high (see Table 2), a 10\% increase would exceed theoretically feasible $\mathrm{CN}$ values, with $\mathrm{CN}=100$ representing a completely impermeable land cover.

The model was run by changing one parameter at a time in the same direction for all HRUs or subbasins. The main water balance components ET, PERC, TLOSS, and FLOW_OUT at Koutine station, and their respective RSI were computed. A total of twelve runs were performed.

\subsubsection{Calibration and validation}

As the SWAT model contains many difficult to measure or non-measurable parameters, especially at the watershed scale, the most sensitive parameters, as identified in the sensitivity analysis, were adjusted based on the 12-year runoff recorded at the outlet of the watershed. Fersi (1985) mentioned that 39 runoff events were observed during the period from September 1973 up to April 1985, but he provided data for 38 events only. For each runoff event, he reported: the runoff depth $(\mathrm{mm})$, the peak flow, the duration of the event (hours) and provided an isohyet map, based on the daily rainfall data from the 6 rainfall stations in and around the watershed. He also reported the daily runoff amounts for these events on a calendar-day basis $(0$ to $24 \mathrm{~h})$. For the modelling we used the daily data. Some small differences were found between the total event runoff and the totals computed from the daily data, which indicates that the accuracy of the data may not have been very high. After 1979, rainfall in Koutine, Allamat, Béni Khédache was recorded by a rainfall recorder. For this period, Fersi (1985) provided hyetographs for 6 events but with the rainfall averaged for the three stations. A few inconsistencies were noticed between the rainfall event totals on the isohyets maps of Fersi and the totals for the reported runoff period obtained from the daily rainfall data reported by DGRE (1968-1985). Apparently, the daily rainfall (08:00 a.m. to 08:00 a.m.) was not always consistently recorded on the correct day. After cross checking between the above data sources and INM (1979-1985), daily rainfall amounts of one or two stations were moved one day backwards or forwards for a few events, based on the occurrence and spatial distribution of the rain at the 6 rain gauges in and around the watershed and the nearby Medenine station (Fig. 1).

A summary of the rainfall and runoff observations of the 38 observed runoff events used for the model evaluation is presented in Table 3. Out of the 38 events, 31 had less than $5 \mathrm{~mm}$ runoff, with all peak flows below $60 \mathrm{~m}^{3} / \mathrm{s}$, while only 3 events had more than $15 \mathrm{~mm}$ runoff. The two largest runoff events were recorded on 12-13 December $1973(30 \mathrm{~mm})$ and on 4-5 March 1979 (42 mm). This last event had a peak flow of $1475 \mathrm{~m}^{3} / \mathrm{s}$. The magnitude of the peak flow was linearly related to the total runoff. The duration of the events ranged between 6 and $54 \mathrm{~h}$; there was no relation between the duration of the events and the total runoff.

The highly variable behaviour of the watershed is evidenced by the watershed runoff coefficients (runoff divided by precipitation). Although the intensity of the rain plays a role in the runoff behaviour of the watershed, as indicated by the higher peak flows for events with higher runoff coefficients, it is also clear that the highly variable distribution of the rain over the $270-\mathrm{km}^{2}$ watershed had an important effect. And obviously, the rain gauges may not always have captured the actual distribution of the rain over the watershed very well. Finally, the increase in vegetation cover during the rainfall season as well as the difference in cover between dry and wet years were also likely to have affected the runoff. Runoff coefficients were slightly higher in autumn (average 0.09, median 0.04) than in winter (average 0.05, median 0.01), when the cereals and annual grasses and herbs have emerged. The majority of the runoff events occurred during the autumn (53\%) and winter months (32\%), few in spring (11\%), while only one event occurred in summer.

Due to the fact that a better rainfall coverage was available for the period September 1978 to August 1985 (6 stations) than for the period September 1973 to August 1978 (4 to 6 stations), the 21 runoff events of the 1978-1985 period were used for calibration and the other 17 events (19731978) were used for validation. Although the validation results may, therefore, not be optimal, this would provide a more robust model parameterization. 
Table 3. Summary of the observed rainfall and runoff characteristics of the 38 runoff events at Koutine watershed during 1973-1985 (sources: Fersi, 1985; INM, 1969-2003).

\begin{tabular}{|c|c|c|c|c|c|c|c|c|c|c|c|c|c|}
\hline \multirow[b]{2}{*}{ Date } & \multirow[b]{2}{*}{ Days $^{1}$} & \multicolumn{8}{|c|}{ Event rainfall } & \multirow[b]{2}{*}{$\begin{array}{r}\text { Runoff } \\
\mathrm{mm}\end{array}$} & \multirow[b]{2}{*}{$\begin{array}{l}\text { Peak } \\
\text { flow } \\
\mathrm{m}^{3} / \mathrm{s}\end{array}$} & \multirow[b]{2}{*}{$\begin{array}{r}\text { Runoff } \\
\text { duration } \\
\mathrm{h}\end{array}$} & \multirow[b]{2}{*}{$\begin{array}{l}\text { Runoff } \\
\text { coeff. }^{4}\end{array}$} \\
\hline & & $\begin{array}{r}\text { Méde } \\
- \text { nine }^{2} \\
\text { mm }\end{array}$ & $\begin{array}{r}\text { Koutine } \\
\mathrm{mm}\end{array}$ & $\begin{array}{r}\text { Allamet } \\
\mathrm{mm}\end{array}$ & $\begin{array}{r}\text { Toujène } \\
\text { Edkhila } \\
\text { mm }\end{array}$ & $\begin{array}{r}\text { Ksar } \\
\text { Jedid } \\
\text { mm }\end{array}$ & $\begin{array}{r}\text { Ksar } \\
\text { Hallouf } \\
\text { mm }\end{array}$ & $\begin{array}{r}\text { Béni } \\
\text { Khédache } \\
\text { mm }\end{array}$ & $\begin{array}{r}\text { Water- } \\
\text { shed }^{3} \\
\mathrm{~mm}\end{array}$ & & & & \\
\hline $21 / 11 / 73$ & 2 & 0.0 & $\mathrm{na}^{5}$ & na & 55 & 3 & 21 & 14 & 25.9 & 7.84 & 248.0 & 20 & 0.30 \\
\hline $13 / 12 / 73$ & 3 & 42.0 & na & na & 107 & 34 & 145 & 115 & 90.8 & 30.46 & 850.0 & 15 & 0.34 \\
\hline 22/09/74 & 1 & 15.0 & na & na & 0 & 0 & 0 & 5 & 2.1 & 0.08 & 18.5 & 11 & 0.04 \\
\hline $19 / 02 / 75$ & 2 & 26.0 & na & na & 50 & 25 & 0 & 60 & 42.6 & 0.12 & 2.7 & 54 & 0.00 \\
\hline $28 / 10 / 75$ & 2 & 66.5 & 34 & na & 35 & 46 & 98 & 32 & 52.2 & 5.98 & 138.0 & 16 & 0.11 \\
\hline $24 / 12 / 75$ & 3 & 40.1 & 23 & na & 52 & 95 & 130 & 138 & 75.2 & 3.85 & 42.0 & 40 & 0.05 \\
\hline $11 / 01 / 76$ & 3 & 29.5 & 51 & na & 51 & 68 & 59 & 57 & 56.0 & 3.18 & 36.0 & 38 & 0.06 \\
\hline $15 / 01 / 76$ & 2 & 49.5 & 86 & na & 70 & 50 & 55 & 85 & 67.1 & 7.11 & 48.0 & 26 & 0.11 \\
\hline $29 / 02 / 76$ & 2 & 6.0 & 2 & na & 29 & 9 & 7 & 28 & 14.2 & 0.13 & 2.0 & 11 & 0.01 \\
\hline $28 / 03 / 76$ & 2 & 13.0 & 43 & na & 43 & 39 & 15 & 26 & 34.7 & 1.14 & 13.0 & 44 & 0.03 \\
\hline $27 / 06 / 76$ & 2 & 6.5 & 0 & na & 0 & 0 & 0 & 13 & 0.5 & 0.29 & 5.3 & 16 & 0.62 \\
\hline 09/10/76 & 2 & 0.0 & 24 & 34 & 56 & 26 & 41 & 23 & 40.5 & 1.43 & 34.5 & 23 & 0.04 \\
\hline $30 / 09 / 77$ & 2 & 4.0 & 48 & 26 & 57 & 27 & 27 & 35 & 36.9 & 0.57 & 7.8 & 37 & 0.02 \\
\hline $10 / 11 / 77$ & 2 & 3.0 & 75 & 43 & 29 & 17 & 0 & 10 & 26.9 & 0.43 & 6.0 & 26 & 0.02 \\
\hline $25 / 11 / 77$ & 1 & 30.0 & 37 & 17 & 0 & 21 & 12 & 4 & 11.9 & 0.19 & 7.0 & 9 & 0.02 \\
\hline $17 / 01 / 78$ & 1 & 0.0 & 28 & 25 & 26 & 24 & 28 & 27 & 26.3 & 0.01 & 0.1 & 14 & 0.00 \\
\hline $10 / 03 / 78$ & 2 & 3.0 & 0.0 & 2.0 & 0.0 & 3.0 & 0.0 & 12.0 & 1.3 & 0.13 & 1.2 & 17 & 0.10 \\
\hline $26 / 10 / 78$ & 2 & 0.0 & 32 & 3 & 7 & 2 & 8 & 3 & 7.0 & 0.21 & 4.5 & 23 & 0.03 \\
\hline $07 / 11 / 78$ & 1 & 0.0 & 8 & 6 & 3 & 4 & 8 & 0 & 5.4 & 0.09 & 0.9 & 19 & 0.02 \\
\hline $26 / 02 / 79$ & 3 & 49.0 & 59 & 52 & 47 & 49 & 71 & 57 & 55.9 & 0.08 & 0.9 & 17 & 0.00 \\
\hline 05/03/79 & 3 & 117.0 & 108 & 169 & 168 & 158 & 168 & 204 & 166.1 & 41.95 & 1475.0 & 26 & 0.25 \\
\hline $10 / 09 / 79$ & 2 & 22.0 & 47 & 30 & 30 & 55 & 0 & 3 & 24.3 & 2.06 & 108.0 & 15 & 0.08 \\
\hline 28/09/79 & 2 & 10.0 & 32 & 8 & 7 & 11 & 14 & 19 & 11.3 & 0.03 & 1.2 & 6 & 0.00 \\
\hline $24 / 11 / 79$ & 2 & 4.0 & 25 & 0 & 3 & 0 & 0 & 0 & 2.3 & 0.28 & 15.4 & 37 & 0.12 \\
\hline $27 / 02 / 80$ & 2 & 1.0 & 32 & 28 & 25 & 44 & 64 & 80 & 39.8 & 1.54 & 28.0 & 36 & 0.04 \\
\hline $13 / 03 / 80$ & 2 & 48.0 & 65 & 6 & 0 & 5 & 0 & 1 & 5.9 & 0.33 & 6.0 & 11 & 0.06 \\
\hline $27 / 09 / 80$ & 1 & 20.0 & 0 & 2 & 0 & 0 & 0 & 0 & 0.6 & 0.00 & 0.1 & 6 & 0.00 \\
\hline $02 / 10 / 80$ & 2 & 8.0 & 16 & 46 & 22 & 15 & 11 & 9 & 25.0 & 0.19 & 4.9 & 18 & 0.01 \\
\hline $20 / 11 / 80$ & 3 & 8.0 & 35 & 25 & 12 & 22 & 70 & 80 & 35.3 & 17.75 & 374.0 & 31 & 0.50 \\
\hline $04 / 12 / 80$ & 2 & 12.0 & 34 & 20 & 12 & 9 & 0 & 3 & 12.1 & 0.06 & 2.5 & 17 & 0.00 \\
\hline $12 / 11 / 82$ & 3 & 28.0 & 17 & 16 & 19 & 23 & 52 & 55 & 28.1 & 1.64 & 27.4 & 14 & 0.06 \\
\hline $07 / 12 / 82$ & 4 & 51.0 & 131 & 70 & 64 & 62 & 48 & 75 & 66.1 & 2.77 & 56.0 & 42 & 0.04 \\
\hline $14 / 10 / 83$ & 2 & 0.0 & 2 & 0 & 0 & 12 & 15 & 26 & 5.8 & 0.48 & 7.2 & 26 & 0.08 \\
\hline $31 / 12 / 83$ & 3 & 62.0 & 39 & 56 & 47 & 57 & 70 & 61 & 56.4 & 0.01 & 0.2 & 8 & 0.00 \\
\hline $10 / 10 / 84$ & 2 & 23.0 & 28 & 37 & 42 & 41 & 42 & 31 & 39.3 & 0.59 & 16.6 & 12 & 0.02 \\
\hline $16 / 10 / 84$ & 2 & 2.0 & 7 & 13 & 83 & 10 & 0 & 0 & 28.6 & 7.01 & 290.0 & 22 & 0.24 \\
\hline $19 / 10 / 84$ & 2 & 14.0 & 14 & 68 & 8 & 3 & 33 & 13 & 32.2 & 0.98 & 21.0 & 24 & 0.03 \\
\hline $29 / 10 / 84$ & 2 & 40.0 & 49 & 37 & 28 & 43 & 15 & 17 & 29.4 & 1.61 & 32.5 & 16 & 0.05 \\
\hline
\end{tabular}

${ }^{1}$ Calendar days with observed and/or simulated runoff; these are not always synchronous because of differences in reporting time of runoff (midnight) and rain (early morning).

2 Rainfall of Médenine is used for simulation of the first two seasons only (1973/74-1974/75).

3 Average rainfall over the watershed computed using SWAT's allocation of subbasins to nearest rain gauge.

${ }^{4}$ Runoff coefficient, ratio of watershed runoff over watershed precipitation.

5 na: not available.

The model parameters were adjusted manually by trial and error using the statistical indicators presented below but also by considering the representativeness of the observed runoff events and the estimated recharge of the study area (Derouiche, 1997). Graphical and statistical measures were used to evaluate the model performance for the calibration and validation periods based on the above mentioned measured data. The statistical criteria used to evaluate the hydrologic goodness-of-fit were the coefficient of determination $\left(R^{2}\right)$ and the model efficiency or Nash-Sutcliffe coefficient (E) (Nash and Sutcliffe, 1970). The coefficient of determination is an index of the degree of linear association between 
Table 4. Parameter values and percent changes to create expected upper and lower boundary values for extreme (minimum and maximum) watershed runoff, with percent changes relative to the final parameter values (Tables 1 and 2).

\begin{tabular}{lrr}
\hline & $\begin{array}{r}\text { Minimum } \\
\text { scenario }\end{array}$ & $\begin{array}{r}\text { Maximum } \\
\text { scenario }\end{array}$ \\
\hline$K_{\text {chan }}(\mathrm{mm} / \mathrm{h})$ & 180 & 30 \\
DIVMAX & $+20 \%$ & $-20 \%$ \\
FLOWFR & $+5 \%$ & $-5 \%$ \\
$K_{\text {soil }}$ & $+50 \%$ & $-50 \%$ \\
AWC & $+50 \%$ & $-50 \%$ \\
CN & $+5 \%$ & $-10 \%$ \\
\hline
\end{tabular}

the observed and the simulated values, but it is highly affected by the good matching records of high values. The Nash-Sutcliffe coefficient indicates how well the plot of observed versus simulated data is close to $1: 1$ line. It is the most often used coefficient in SWAT calibrations (Gassman et al., 2007), although it is also affected by high values. The optimal value of the model efficiency is 1 . It is calculated as follows:

$E=1-\frac{\sum_{i=1}^{n}(O i-P i)^{2}}{\sum_{i=1}^{n}(O i-\bar{O})^{2}}$

where $O_{i}$ is the observed value, $P_{i}$ is the predicted value, $O$ is the average value and $n$ is the number of observed values ( 21 for the calibration and 17 for the validation). In addition, we used also the mean absolute error (MAE) index which is a statistical estimator to show how much the model over or under-estimates the observations. It is defined as:

MAE $=\left(\sum_{1}^{n}\left|O_{i}-P_{i}\right|\right) / n$

To capture some of the uncertainty in the parameter values, two additional runs were performed: one with the combination of the extreme parameter value settings that would result in maximum outflow from the watershed and one with the combination that would result in minimum outflow. The same expected upper and lower limits were used as for the sensitivity analysis but the percent changes were relative to the calibrated parameter values (Table 4). The simulated extreme runoff was compared with the observed watershed runoff.

Finally, a comparison of the water balance components of wadi Koutine obtained with SWAT-WH and the results that were obtained with the original SWAT2000 version, without water harvesting, is made.

\section{Results and discussion}

\subsection{Sensitivity analysis}

The results of the sensitivity analysis tests at the watershed level are given in Table 5. The simulations with the base parameter set for the 1973-1985 period resulted in the following distribution of the incoming precipitation $(209 \mathrm{~mm} / \mathrm{yr}$ average) for the watershed: $72 \%$ evapotranspiration, $19 \%$ percolation, $6 \%$ outflow from the watershed and 3\% transmission losses through the wadi bed. As compared to the estimates obtained from previous studies (Fersi, 1985; Derouiche, 1997), the expected range of the selected key parameters kept the average annual runoff (4-8\% of the precipitation) within the same range as the observed data (6\%) reported by Fersi (1985), but the evapotranspiration (58$80 \%$ ) remained always underestimated as compared with the 88\% obtained from the studies of Fersi (1985) and Derouiche (1997) . The computed water balance components were most sensitive to CN and FLOWFR, and to a lesser extent to AWC and $K_{\text {chan }}$. Because the CN controls the first step in the water routing cycle by the subdivision of the rainfall into runoff and infiltration, it had a major impact on all water balance components.

The relative sensitivity of the simulated average annual flow out of the watershed to a change in the $\mathrm{CN}$ was 7.54 for a $5 \%$ increase and 6.77 for a $10 \%$ decrease in the $\mathrm{CN}$ values. These were far higher than the relative sensitivities to the FLOWFR, which were -0.85 and -0.91 , respectively. Interestingly, the simulated FLOW_OUT was much less sensitive to the height of the harvested water on the jessour and tabias (DIVMAX) than to the fraction of runoff water harvested, with a relative sensitivity of -0.34 for a $20 \%$ increase and 0.22 for a $20 \%$ decrease in the value of DIVMAX. The lower sensitivity to an increase in DIVMAX, as compared to a decrease, indicated that not all events filled the waterharvesting structures up to their capacity.

As expected, the AWC had an important effect on ET and PERC. A 50\% increase in the AWC (assumed to represent a change in soil depth as well as in water holding capacity), increased the ET from 72 to $78 \%$ of the total rainfall and reduced the percolation from 19 to $12 \%$. A $50 \%$ reduction of the AWC reduced the ET from 72 to $58 \%$ of the rainfall and increased the percolation from 19 to $33 \%$. As the $K_{\text {soil }}$ values in the watershed are relatively high, it was found not to be a sensitive parameter. The FLOWFR, and to a less extent the DIVMAX, also affected percolation because these parameters control the amount of water captured by the water-harvesting systems, with downwards drainage mainly occurring from the relatively shallow soils $(1 \mathrm{~m})$ of the tabias.

Clearly, FLOW_OUT is most sensitive to the CN, followed by the FLOWFR and DIVMAX. Therefore, these three parameters were selected for the calibration. 
Table 5. The water balance components, expressed as a percentage of the precipitation over the watershed, and their relative sensitivities (RSI) to selected model parameters for the 1973-1985 evaluation period.

\begin{tabular}{|c|c|c|c|c|c|c|c|c|}
\hline & \multicolumn{4}{|c|}{ RSI } & \multicolumn{4}{|c|}{ Water balance components $(\%)$} \\
\hline & ET & PERC & TLOSS & FLOW_OUT & ET & PERC & TLOSS & FLOW_OUT \\
\hline Base scenario & - & - & - & - & 72.2 & 18.8 & 2.8 & 6.0 \\
\hline$K_{\text {chan }}=180$ & 0.00 & 0.00 & 0.31 & -0.15 & 72.2 & 18.8 & 4.2 & 4.6 \\
\hline$K_{\text {chan }}=30$ & 0.00 & 0.00 & 0.73 & -0.35 & 72.2 & 18.8 & 1.7 & 7.2 \\
\hline DIVMAX $+20 \%$ & 0.00 & 0.09 & -0.10 & -0.22 & 72.2 & 19.1 & 2.8 & 5.7 \\
\hline DIVMAX-20\% & 0.00 & 0.11 & -0.01 & -0.34 & 72.2 & 18.4 & 2.9 & 6.4 \\
\hline FLOWFR+5\% & 0.07 & 0.43 & -2.69 & -0.85 & 72.4 & 19.2 & 2.5 & 5.8 \\
\hline FLOWFR-5\% & 0.06 & 0.35 & -1.79 & -0.91 & 71.9 & 18.5 & 3.1 & 6.3 \\
\hline$K_{\text {soil }}+50 \%$ & 0.00 & -0.01 & 0.02 & 0.01 & 72.2 & 18.7 & 2.9 & 6.0 \\
\hline$K_{\text {soil }}-50 \%$ & 0.00 & -0.01 & 0.02 & 0.00 & 72.1 & 18.9 & 2.8 & 6.0 \\
\hline $\mathrm{AWC}+50 \%$ & 0.21 & -0.74 & -0.19 & -0.20 & 79.7 & 11.9 & 2.6 & 5.4 \\
\hline AWC-50\% & 0.39 & -1.51 & 0.01 & -0.04 & 57.9 & 33.0 & 2.8 & 6.1 \\
\hline $\mathrm{CN}+5 \%$ & -0.45 & -1.65 & 7.94 & 6.77 & 70.5 & 17.3 & 4.0 & 8.0 \\
\hline $\mathrm{CN}-10 \%$ & 0.67 & -6.43 & 9.40 & 7.54 & 69.7 & 24.9 & 1.5 & 3.7 \\
\hline
\end{tabular}

Input parameters: DIVMAX: maximum level of the pounded water on the water-harvesting fields; AWC: available water capacity; $\mathrm{K}_{\text {soil }}$ : soil hydraulic conductivity $(\mathrm{mm} / \mathrm{h})$; $\mathrm{CN}$ : Curve number; $K_{\mathrm{chan}}$ : hydraulic conductivity of the stream channel bottoms (mm/h); FLOWFR: fraction of runoff flow diverted to water-harvesting systems. Model outputs: ET: Evapotranspiration; PERC: Percolation; TLOSS: transmission losses; FLOW_OUT: stream flow at the watershed outlet.

\subsection{Calibration and validation}

The results of the base run indicated that for high rainfall events in the upstream areas runoff was generally underestimated by the model, whereas for events with high rainfall in the mid- and downstream areas runoff was overestimated. As FLOW_OUT is most sensitive to the $\mathrm{CN}$, adjustments were made to the $\mathrm{CN}$ as shown in Table 2. To reduce the runoff in the mid- and downstream area, the $\mathrm{CN}$ of the cereals and the rangelands in the plain was reduced. However, the reduction of the $\mathrm{CN}$ is constrained by the shallowness of the majority of the soils covered by these land uses. These shallow soils fill up quickly, with the remainder of the rain turning in to runoff, lateral flow and percolation. The mountain rangelands on the soils in the downstream areas (ISOH, PEAH) were assumed to have similar $\mathrm{CNs}$ as the plain rangelands on these soils. For the mountain rangelands on the shallow soils (MBEH, CRCG), which are mainly found on the sloping lands in the upstream and midstream areas, the $\mathrm{CN}$ was increased by 2 points. Because the area occupied by jessour seemed to be somewhat overestimated, the DIVMAX of jessour was reduced from 0.25 to $0.22 \mathrm{~m}$, which also increased the runoff from the upstream areas. The FLOWFR of the tabias, which capture a large part of the runoff of the upstream areas, was reduced from 95 to $90 \%$.

The $R^{2}$ of the 21 calibrated runoff events was 0.77 and the Nash-Sutcliffe coefficient was 0.73 . A graphical representation of the observed versus simulated outflow of the recorded events at Koutine station is presented in Fig. 5. As can be seen, the calibrated events (September 1978-August 1985) fitted the observed events reasonably well. For the 17 validation events, the fit was not as good, an $R^{2}$ of 0.44 and an $E$ of 0.43 were obtained. The MAEs of the calibration and validation periods were 2.6 and $3.0 \mathrm{~mm}$, respectively.

The validation period clearly suffered from the absence of the Koutine and Allamet rain gauges, which cover most of the downstream and midstream areas. In their absence, the rain was interpolated from the remaining four rain gauges plus the Médenine station. The lack of rain gauges in the downstream area resulted in an underestimation of three of the four runoff events observed during this period. The Koutine gauge, which is located near the outlet, became operational in September 1975 and the Allamet gauge in September 1976. During the 1975-76 season, the rain over the lower midstream area was covered by the downstream Koutine rain gauge, which resulted in the opposite effect, with five of the seven events overestimated.

It is important to note that $50 \%$ of the total runoff of the 12 -year period is produced by two events. The largest event, which occurred in March 1979 (calibration period), had an area-weighted rainfall of $166 \mathrm{~mm}$ over the watershed and an observed runoff of $42 \mathrm{~mm}$. This event was estimated quite well by the model $(47 \mathrm{~mm})$. The second largest event, on December 1973 (validation period), which received $91 \mathrm{~mm}$ rain and $30 \mathrm{~mm}$ runoff, was clearly underestimated $(12 \mathrm{~mm})$ and the observed runoff did not even fall inside the boundaries of the extreme parameter sets (Fig. 7). This was most likely at least partly due to absence of both the Koutine and the Allamet rain gauges. 

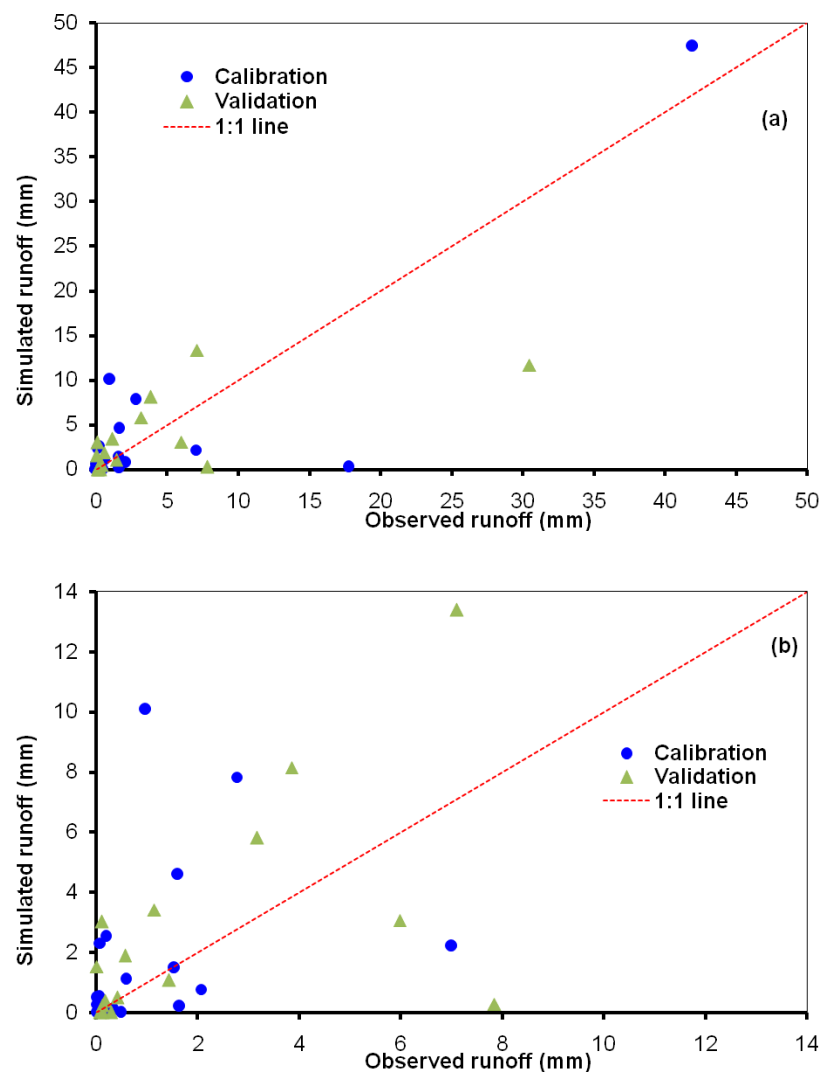

Fig. 5. Simulated versus observed watershed runoff (a whole period; b events less than $20 \mathrm{~mm}$ ) for the 38 events in Wadi Koutine.

If we exclude this 91-mm rain event from the validation record, the MAE becomes obviously smaller $(2.1 \mathrm{~mm})$. However, the $R^{2}$ is reduced from 0.44 to 0.33 and the NashSutcliff coefficient becomes negative $(-.034)$, indicating that the observed mean is a better estimator than the simulated runoff. Thus, while the model is capable of capturing the general runoff behavior of the watershed, the accuracy of the data is not sufficient for simulating the diversity of the small events.

Clearly, the highly variable spatial distribution of the rainfall, which frequently occurs in dry regions, combined with the variable land use and locations of jessour and tabias, induces problems. For the same area weighted average rainfall over the watershed we can obtain contrasting responses. As expected, better model fits were generally obtained for high and uniformly distributed rainfall events.

Except for the varying distributions of the rainfall over the watershed, and the somewhat inadequate coverage of the rain gauges, differences in the intensity of the rainfall also affected the observed rainfall-runoff relations in the watershed. The highest reported 30-min maximum intensity $(76 \mathrm{~mm} / \mathrm{h})$, which is the reported average of the Béni Khédache, Allamet and Koutine rain gauges (Fersi, 1985), was recorded for a 23-mm rainfall event on 15 October 1984. This event in-
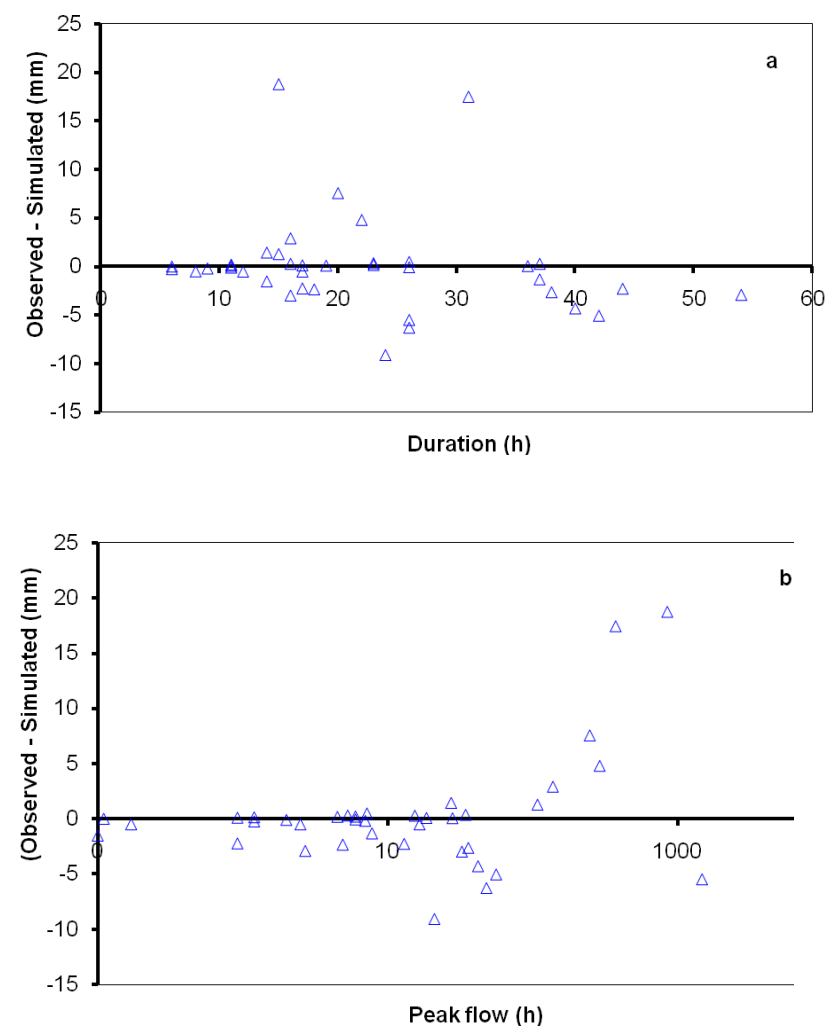

Fig. 6. Model error (observed minus simulated runoff) versus duration (a) and observed peak flow (log-scale) (b) for the 38 events in Wadi Koutine.

deed produced high runoff $(7 \mathrm{~mm})$. During the same month (29 October 1984), the reported maximum 30-min intensity of a seemingly similar rainfall event $(27 \mathrm{~mm})$ was $24 \mathrm{~mm} / \mathrm{h}$. As expected, this event produced much less runoff $(1.6 \mathrm{~mm})$ than the previous event. The SWAT-WH simulations of these events were affected by the different initial soil moisture conditions and by the spatial distribution of the rainfall. The first event, which occurred mainly in the midstream areas (Allamet and Toujène Edkhila) had a simulated runoff of $2.2 \mathrm{~mm}$, whereas the second event, which covered the complete watershed had a simulated runoff of $4.6 \mathrm{~mm}$. The daily time step is thus seen to be too coarse to represent high intensity events adequately.

To obtain a better understanding of the possible effect of rainfall intensities, the runoff simulation errors were plotted versus the duration of the events and versus the observed peak flows (Fig. 6). As can be seen in this figure, the model tended to overestimate the events with longer duration and lower peak flows, and underestimated the events with higher peak flows. For the shorter duration events more balanced model results are obtained. These results indicated that the higher intensity events can not be simulated very well by the available daily data and runoff computation procedure. 

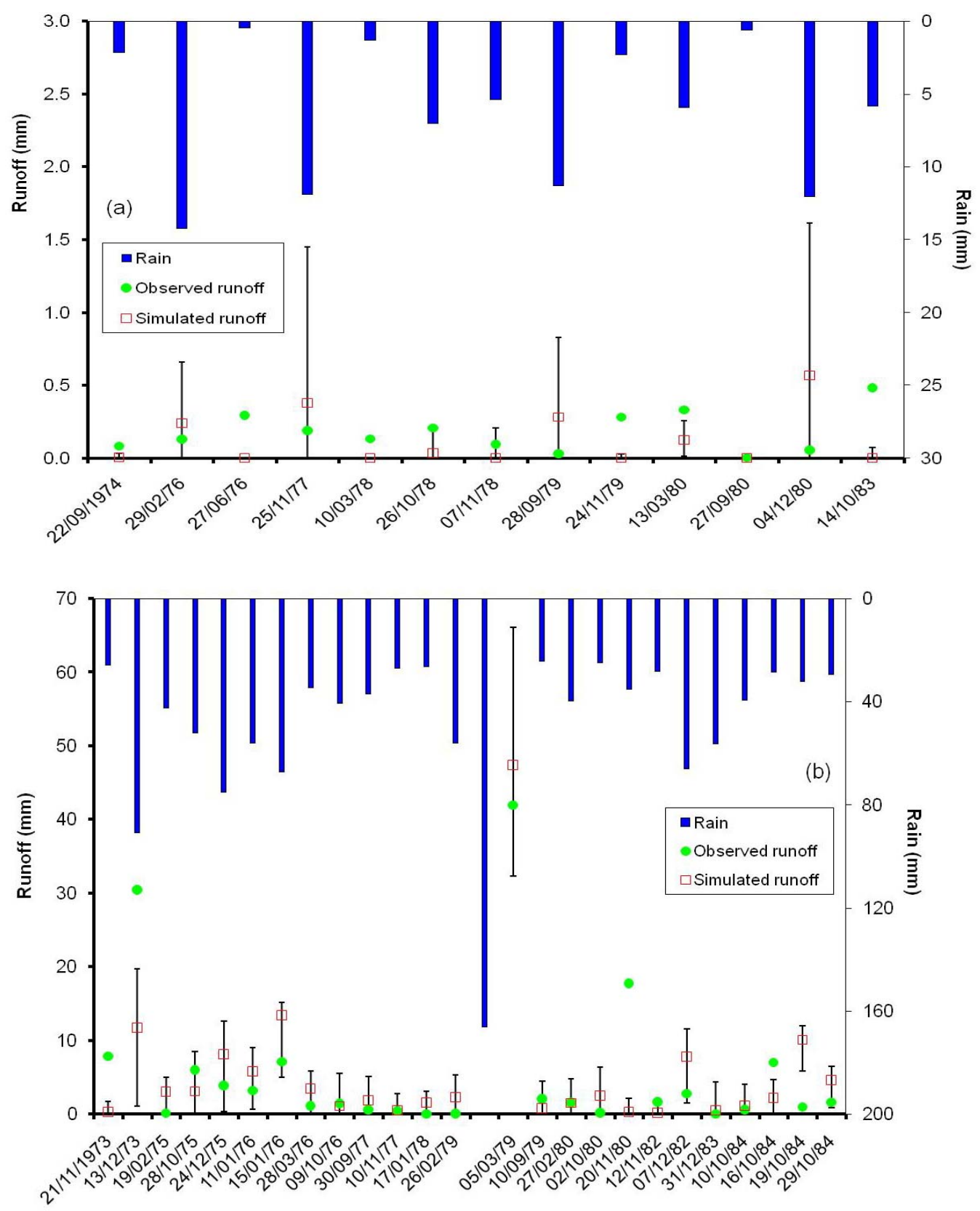

Fig. 7. Rainfall, observed and simulated runoff and the simulated minimum and maximum error bounds for events with less than $20 \mathrm{~mm}$ rain (a) and more than $20 \mathrm{~mm}$ rain (b). The events after 1 September 1978 were calibrated.

As can be seen in Fig. 7, the majority of the observed runoff events fitted between the minimum and maximum bounds obtained with the extreme parameter sets, but thirteen of the observed events had higher observed runoff than the maximum simulated runoff and two events (19 February 1975 and 19 October 1984) had lower runoff than the minimum simulated runoff. As discussed previously, it is very likely that these events suffered from inadequate representation of the spatial and temporal distribution of the precipitation and measurement inaccuracies.
Although the performance indicators are relatively low, the calibrated model captured the average annual runoff for the watershed quite well. The calibrated model predicted an average annual flow out of the watershed of $12 \mathrm{~mm}$ which is similar to the $11.9 \mathrm{~mm}$ computed from the runoff observations presented by Fersi (1985). Although Fersi (1985) mentioned only one runoff event not being recorded, it is likely that some other events may not have been recorded as well. In addition to the observed events, the model predicted runoff rates of more than $0.01 \mathrm{~mm} / \mathrm{d}$ for about 40 daily events 
Table 6. Water balance components from the different land uses, as calculated by SWAT and SWAT-WH.

\begin{tabular}{|c|c|c|c|c|c|c|c|c|c|c|}
\hline & \multicolumn{2}{|c|}{ STPP $^{1}$} & \multicolumn{2}{|c|}{ STPJ } & \multicolumn{2}{|c|}{ CULT } & \multicolumn{2}{|c|}{ OLVP } & \multicolumn{2}{|c|}{ OLVM } \\
\hline & SWAT & SWAT-WH & SWAT & SWAT-WH & SWAT & SWAT-WH & SWAT & SWAT-WH & SWAT & SWAT-WH \\
\hline Precipitation (mm) & 209 & 209 & 209 & 209 & 209 & 209 & 209 & 209 & 209 & 209 \\
\hline Evapotranspiration (mm) & 127 & 117 & 107 & 106 & 106 & 114 & 168 & 187 & 189 & 277 \\
\hline Percolation (mm) & 18 & 23 & 12 & 15 & 9 & 21 & 20 & 66 & 2 & 88 \\
\hline Runoff and lateral flow (mm) & 64 & 69 & 90 & 88 & 94 & 75 & 22 & 0 & 18 & 0 \\
\hline
\end{tabular}

${ }^{1}$ STPP: Rangelands of the plains; STPJ: Rangelands of the mountains; CULT: Cereals; OLVP: Olives of plains (tabias); OLVM: Olives of the mountains (jessour).

during the 12-year period. However, the model behaved similarly to the observed record (i.e., no runoff) for the remaining records (253 rain days).

\subsection{Water balance components}

For the calibrated parameter set, the model predicted that the average annual rainfall of the 12-year evaluation period over the area of the watershed $(209 \mathrm{~mm})$, mainly goes to ET $(150 \mathrm{~mm}, 72 \%)$, then to percolation $(39 \mathrm{~mm}, 19 \%)$, to stream flow at the outlet of the watershed $(12 \mathrm{~mm}, 6 \%)$ and to transmission losses $(6 \mathrm{~mm}, 3 \%)$. The simulated growth and evapotranspiration of the olives, cereals and rangelands with SWAT-WH seemed realistic and yields were comparable with locally measured values. However, more detailed data collection is needed for the evaluation of the crop growth modules.

The computed water balance components indicated rather high average annual groundwater recharge rates $(22 \%$ of the average annual rainfall) compared to the $6 \%$ reported by Derouiche (1997). However, Derouiche (1997) calibrated and computed the recharge for the deep aquifer system, whereas the watershed also has some local, shallow aquifers (underflow aquifers). In addition, the roots of the olive trees and the native rangeland vegetation extract water from the upper cracked parts of the bedrock. It should also be noted that SWAT moves all of the precipitation that does not run off in to the soil profile, while in reality part of the precipitation is stored in small surface depressions and ponds. Thus, not all of the percolation from the soils, computed by SWAT, may end up in the deep aquifer. Obviously, the percolation rate is also affected by the soil depths and AWC, but even a $50 \%$ increase in the AWC of the watershed still gave a percolation of $12 \%$ of the average annual precipitation (see Table 5).

Studies in similar arid environments reported annual recharge rates ranging from 3 to $15 \%$ of the precipitation. For example, Osterkamp et al. $(1994,1995)$ reported a total average annual recharge of $3 \%$ of the rain $(180 \mathrm{~mm})$ in California, and $7 \%$ of the rain $(130 \mathrm{~mm})$ in Oman (Al Ain), whereas Barnes et al. (1994) found that the transmission losses and percolation represented $15 \%$ of the rain $(278 \mathrm{~mm})$ in an arid region of Australia. But it should be noted that the water harvesting structures, which cover large parts of our watershed, also provide an important contribution to the percolation, as can be seen in Table 6 .

The results of a model run with the original SWAT2000 version, here referred to as SWAT, are also presented in Table 6 . Without the harvesting of surface runoff, the percolation from the jessour (OLVM) was reduced from $88 \mathrm{~mm}$ (SWAT-WH) to $2 \mathrm{~mm}$ (SWAT) and from 66 to $20 \mathrm{~mm}$ for the tabias (OLVP). While the total percolation from the soils of the watershed was $6 \%$ of the incoming precipitation, as compared to $19 \%$ with SWAT-WH. Obviously, the original SWAT could not simulate the higher ET rates from the waterharvesting units. The ET of the jessour was reduced from $277 \mathrm{~mm}$ for the SWAT-WH simulations to $189 \mathrm{~mm}$ for SWAT and the ET of the tabias was reduced from 187 to $168 \mathrm{~mm}$. However, it should be mentioned that SWAT-WH also includes modifications of the crop growth processes and of the change in $\mathrm{CN}$ values during the season (simulated by tillage practices).

The runoff from most units was higher for the SWAT simulations than for the SWAT-WH simulations, but these results were also affected by the changes in $\mathrm{CN}$ during the growing season, as simulated with tillage operations, which did not function in SWAT2000, and by the adjustments made in the crop growth module. The flow out of the watershed and the transmission losses from the stream for the SWAT simulation were 13 and $12 \%$ of the incoming precipitation, respectively, as compared to 6 and $3 \%$ for SWAT-WH. Thus, with the same model parameter values, overall recharge would also be overestimated by SWAT.

The sloping area (mountains rangelands) produced more surface runoff than the piedmont and flat area (plain rangelands). Because of the higher runoff but also because of the higher ratio of rangeland versus water-harvesting in the mountains as compared to the plains, the olives of the mountains collected more runoff (156 versus $44 \mathrm{~mm}$ ) than those of the plains. Most of this difference went into ET $(90 \mathrm{~mm})$. These results are along the lines of the differences 
in productivity of these systems. This explains to some extent also the settlement and cropping pattern of the watersheds in the dry areas, where the farmers started upstream and gradually moved downstream.

\section{Conclusions}

The GIS-based model SWAT (version 2000) was adapted and evaluated for water balance assessments in arid watersheds with water-harvestings systems. The main changes were the redistribution of runoff water within a subbasin to represent different water-harvesting systems (jessour and tabias), and adjustments of the crop growth processes to simulate cereal and olive production in Mediterranean environments. We denoted the adapted model as SWAT-WH (SWAT for Water Harvesting). The model was evaluated for the $272-\mathrm{km}^{2}$ Koutine watershed in southeast Tunisia, using 38 runoff events recorded between 1973 and 1985 .

The runoff record provided a prime example of the highly variable behaviour of arid watersheds, with runoff coefficients for the 38 events varying between less than $1 \%$ and $62 \%$. However, these rainfall-runoff relations were affected by the low density of the rain gauge network and possible measurement inaccuracies. A reasonable representation of the majority of these events could be obtained with SWATWH through calibration of the CN, the FLOWFR, and DIVMAX.

The runoff process is also affected by the rainfall intensities, which are not directly captured by the $\mathrm{CN}$ method. Although SWAT can also use the Green-Ampt method for runoff calculations, the required detailed breakpoint rainfall data are not available for the study site. Despite the limitations of the $\mathrm{CN}$ method, it is still widely used because of lack of rainfall intensity data. Therefore, better $\mathrm{CN}$ estimates are needed through the monitoring of rainfall, runoff and characteristics of jessour and tabias for small, relatively uniform watersheds. However, it is important that any future monitoring efforts include continuous measurements, such that comparisons between the $\mathrm{CN}$ and other runoff and infiltration models can be made.

Although SWAT-WH allows a reasonable representation of the water balance components and processes of the different soil and land uses at the subbasin level, it does not allow the routing of surface runoff between different land units within the subbasins. Therefore, to evaluate the long term hydrologic impact and the dynamics of the water-harvesting structures, SWAT-WH could be coupled with a cell-based routing model at the subbasin level.

A disadvantage of SWAT is that it forces all precipitation that does not runoff to enter the soil profile. With the predominating shallow and sandy textured soils in the watershed, this resulted in the simulation of high percolation rates. However, it is likely that part of the water is stored in small surface depressions. In some soils water is also stored in the upper, cracked parts of the bedrock, from which it is subsequently extracted by vegetation. Therefore, not all of the computed percolation may contribute to groundwater recharge. Thus, a more accurate estimation of groundwater recharge would require a ponding routine. The cracked bedrock could probably be simulated in SWAT as an additional soil layer. However, detailed monitoring of water movement in the vadose zone is needed to obtain a better understanding of the flow and recharge processes.

Another groundwater recharge process simulated by SWAT is the transmission loss from the stream. However, these results are difficult to evaluate because of a general scarcity of field observations. Thus, successive wadi flow stations, as suggested by Shentis et al. (1999), should be installed at selected sections of the main wadi network to allow a better computation of the transmission losses and hydraulic conductivity of the channel bed. These data could also be useful for groundwater flow and other model applications (e.g. MODFLOW).

An important asset of SWAT is that it also simulates crop production and management processes, thus, allowing the estimation of water productivity and economic evaluation of alternative water management scenarios. This is especially opportune for the allocation of scarce water resources in the dry areas. However, crop growth and production studies are needed to develop local crop growth parameters and to evaluate the crop growth model for these arid environments.

Acknowledgements. The authors are grateful for the financial assistance provided by the Foreign Agricultural Service of the United States Department of Agriculture (USDA-FAS), which supported the work for this paper. We would also like to thank the reviewers and the editor for their suggestions and comments, which helped us to improve the paper.

Edited by: S. White

\section{References}

Alaya, K., Viertmann, W., and Waibel, Th. (Eds.): Les tabias, Imprimerie Arabe de Tunisie, Tunis, Tunisia, 1993.

Allen, R. G., Pereira, L. S., Raes, D., and Smith, M.: Crop evapotranspiration, guidelines for computing crop water requirements, FAO Irrigation and Drainage Paper No 56, Rome, Italy, 1998.

Allen, R. G.: A Penman for all seasons, Journal of Irrigation and Drainage Engineering, 112(4), 348-368, 1986.

Arnold, J. G., Srinivasan, R., Muttiah, R. S., and Williams, J. R.: Large area hydrologic modeling and asssement. Part I: Model development, J. Am. Water Resour. As., 34(10), 73-89, 1998.

Arnold, J. G., Srinivasan, R., Muttiah, R. S., and Allen, P. M.: Continental scale simulation of the hydrologic balance, J. Am. Water Resour. As., 35(5), 1037-1051, 1999.

Barnes, C. J., Jacobson, G., and Smith, G. D.: The distributions recharge mechanism in the Australian arid desert, Soil Sci. Soc. Am. J., 58, 31-40, 1994.

Ben Mechlia, N. and Ouessar, M.: Water harvesting systems in Tunisia, in: Indigenous water harvesting in West Asia and North 
Africa, edited by: Oweis, T., Hachum, A., and Bruggeman, A., ICARDA, Aleppo, Syria, 21-41, 2004.

Bingner, R. L., Garbrecht, J., Arnold, J. G., and Srinivasan, R.: Effect of watershed division on simulation of runoff and fine sediment yield, Transactions of the American Society of Civil Engineers, 40(5), 1329-1335, 1997.

Boers, Th. M. (Ed.): Rainwater harvesting in arid and semi-arid zones, Publication 55, ILRI, Wageningen, 1994.

Borah, D. K. and Bera, M.: Watershed scale hydrologic and nonpoint source pollution models: Review of applications, Transactions of the American Society of Agricultural Engineers, 47(3), 789-803, 2004.

Bouraoui, F., Benabdallah, S., Jrad, A., and Bidoglio, G.: Application of the SWAT model on the Medjerda river basin (Tunisia), Phys. Chemi. Earth, 30, 497-507, 2005.

Bruggeman, A. and van der Meijden, G.: Assessment of water use in a small watershed in Northern Syria using SWAT, in: Proceedings of the $3^{r d}$ international SWAT conference, edited by: Srinivasan, R., Jennifer, J., Day, D., and Abbaspour, K., Zurich, 11-15 July 2005, 50-60, 2005.

Chahbani, B.: Contribution à l'étude de la destruction des jessour dans le sud tunisien, Revue des Régions Arides, 1, 137-172, 1990.

Chaponniere, A.: Fonctionnement hydrologique d'un bassin versant montagneux semi-aride : Cas du bassin versant du Rehraya (Haut Atlas Marocain), Ph.D. thesis, Centre d'Etudes Spatiales de la Biosphère, Paris, 2005.

Cho, S. M., Jennings, G. D., Stallings, C., and Devine, H. A.: GIS-based water quality model calibration in the Delaware river basin, American Society of Agricultural Engineers Microfiche No. 952404, St. Joseph, MI, 1995.

Chow, V. T., Maidment, D. R., and Mays, L.W. (Eds.): Applied Hydrology. McGrawHill, New York, USA, 1988.

Chu, T. W. and Shirmohammadi, A.: Evaluation of the SWAT model's hydrology component in the piedmont physiographic region of Maryland, Transactions of the American Society of Agricultural Engineers, 47(4), 1057-1073. 2004.

Conan, C., de Marsily, G., Bouraoui, F., and Bidoglio, G.: A longterm hydrological modelling of the upper Guadiana river basin (Spain), Phys. Chem. Earth, 28, 193-200, 2003.

CPCS (Commission de Pédologie et de Cartographie des Sols): Classification française des sols, INRA, Paris, 1967.

Derouiche, R.: Contribution à l'étude par modèle numérique de l'impact des aménagements de CES sur la recharge de la nappe de Zeuss-Koutine, M.Sc thesis, Institut National Agronomique, Tunis, Tunisia, 1997.

DGRE (Direction Générale des Ressources en Eau): Annuaire pluviométrique (1979-1985), Ministère de l'Agriculture, Tunis, Tunisia, 1985.

Djebbi, M.: MULTIC: logiciel de simulation des aquifers multicouches en mailles carrées régulières, guide d'utilisation, Ecole National des Ingénieurs, Tunis, Tunisia, 1992.

El Amami, S. (Ed.): Les aménagements hydrauliques traditionnels en Tunisie, Centre de Recherche en Génie Rural, Tunis, Tunisia, 1984.

FAO : Légende de la carte mondiale des sols, FAO/UNESCO, Rome, 1989.

Fersi, M. (Ed.): Etude hydrologique d'oued Oum Zessar à Koutine, Ministère de l'Agriculture, Tunis, 1985.
Fleskens, L., Stroosnijder, L., Ouessar, M., and De Graaff, J.: Evaluation of the onsite impact of water harvesting in Southern Tunisia, J. Arid Environ., 62, 613-630, 2005.

Floret, C. and Pontanier, R. (Ed.): L'aridité en Tunisie présaharienne: Climat, sol, végétation et aménagement, ORSTOM, Paris, 1982.

Gassman, P. W., Reyes, M., Green, C. H., and Arnold, J. G.: The Soil and Water Assessment Tool: Historical Development, Applications, and Future Directions, CARD Working Paper 07-WP 443, Center for Agricultural and Rural Development, Iowa State University, 2007.

Gee, G. W. and Bauder, J. W.: Particle-size analysis, in: Methods of soil analysis, Part 1: Physical and mineralogical methods, Agronomy Monograph no. 9 (2nd edition), edited by: Klute, A., Am. Soc. gron.-Soil Sci. Soc. Am., Madison, WI, 383-411, 1986.

Green, W. H. and Ampt, G. A.: Studies on soil physics, 1. The flow of air and water through soils, Journal of Agricultural Sciences, 4, 11-24, 1911.

Hargreaves, G. H. and Samani Z. A.: Reference crop evapotranspiration from temperature, Appl. Eng. Agric., 1, 96-99, 1985.

Heuvelmans, G., Muys, B., and Feyen, J.: Evaluation of hydrological model parameter transferability for simulating the impact of land use on catchment hydrology, Phys. Chem. Earth, 29, 739747, 2004.

INM (Institut National de la Météorologie): Bulletin agrométéorologique décadaire (1979-1985), INM, Tunis, Tunisia, 1985.

Kaur, R., Srinivasan, R., Mishra, K., Dutta, D., Prasad, D., and Bansal, G.: Assessment of a SWAT model for soil and water management in India, Land Use and Water Resources Research, 3, 1-7, 2003.

Labras, A.: Analyse comparée de l'opportunité technicoéconomique de l'oléiculture en plaine et en montagne dans le sud-est tunisien, Graduation thesis, Ecole Supérieure d'Agriculture, Mograne, Tunisia, 1996.

Lane, L. J.: Transmission losses, National Engineering Handbook (Section 4), USDA, 1983.

Lenhart, T., Eckhardt, K., Fohrer, N., and Frede, H. G.: Comparison of two different approaches of sensitivity analysis, Phys. Chem. Earth, 27, 645-654, 2002.

Maati, M.: Impact des aménagements de CES sur le bassin versant en zones arides cas de Oum Zessar, Graduation thesis, Ecole Supérieure des Ingénieurs de l'Equipement Rural, Mjez El Bab, Tunisie, 2001.

Monteith, J. L.: Climate and the efficiency of crop production in Britain. Philosophical Transactions of the Royal Society of London, 281, 277-329, 1977.

Nash, J. E. and Sutcliffe, J. V.: River flow forecasting through conceptual models: Part I. A discussion of principles, J. Hydrol., 10(3), 282-290, 1970.

Neffati, M.: Caractérisation morpho-biologique de certaines espèces végétales Nord Africaines: Implications pour l'amélioration pastorale, Ph.D. thesis, Ghent University, Ghent, Belgium, 1994.

Neitsch, S. L., Arnold, J. G., Kiniry, J. R., Williams, J. R., and King, K. W.: Soil and water assessment tool theoretical documentation: version 2000, Texas water resources institute, College station, Texas, USA, 2002. 
Neitsch, S. L., Arnold, J. G., Kiniry, J. R., Williams, J. R., and King, K. W.: Soil and water assessment tool theoretical documentation: version 2005, Texas water resources institute, College station, Texas, USA, 2005.

Osterkamp, W. R., Lane, L. J., and Menges, C. M.: Techniques for ground-water recharge estimates in arid/semi-arid areas, with examples from Abu Dhabi, J. Arid Environ., 31, 349-369, 1995.

Osterkamp, W. R., Lane, L. J., and Savard, C. S.: Recharge estimates using geomorphic/distributed-parameter simulation approach, Amargosa river basin, Water Resour. Bull., 30(3), 493507, 1994

Ouessar, M., Yahyaoui, H., Ouled Belgacem, A. and Boufalgha, M.: Aménagements et techniques de lutte contre la désertifcation: inventaire et bilan, in: Entre la désertification et le développement: la Jeffara tunisienne, edited by: Genin, D., Guillaume, H., Ouessar, M., Ouled Belgacem, A., Romagny, B., Sghaier, M., and Taamallah H., CERES Editions, Tunis, Tunisia, 147-161, 2006.

Ouessar, M. and Yahyaoui, H.: Les ressources en eau, in: Entre la désertification et le développement: la Jeffara tunisienne, edited by: Genin, D., Guillaume, H., Ouessar, M., Ouled Belgacem, A., Romagny, B., Sghaier, M., and Taamallah H., CERES Editions, Tunis, Tunisia, 47-56, 2006.

Ouled Belgacem, A.: Statut écologique performance biologique et aptitude a la réinstallation de Stipa lagascae dans les écosystèmes dégradés des milieux arides tunisiens, Ph.D. thesis, Faculté des Sciences, Sfax, Tunisia, 2006.

Oweis, T., Hachum, A., and Bruggeman, A. (Eds.): Indigenous water harvesting in West Asia and North Africa, ICARDA, Aleppo, Syria, 2004.

Ponce, V. P. and Hawkins, R. H.: Runoff curve number: Has it reached maturity?, J. Hydrol. Eng., 1(1), 11-18, 1996.

Priestley, C. H. B. and Taylor, R. J.: On the assessment of surface heat flux and evaporation using large-scale parameters, Mon. Weather Rev., 100, 81-92, 1972.

Santhi, C, Arnold, J. G, Williams, J. R, Dugas, W. A, Srinivasan, R., and Hauck, L. M.: Validation of the SWAT model on a large river basin with point and nonpoint sources, J. Am. Water Resour. As., 37(5), 1169-1188, 2001.

Saxton, K. E.: Soil water characteristics hydraulic properties calculator, online available at: http://hydrolab.arsusda.gov/soilwater/ Index.htm, 2005.
SCS (Soil Conservation Service Engineering Division): Urban hydrology for small watersheds. U.S. Department of Agriculture, Technical Release 55, 1986.

SCS (Soil Conservation Service): Section 4: Hydrology, National Engineering Handbook, SCS, 1972.

Sharpley, A. N. and Williams, J. R.: EPIC-Erosion Productivity Impact Calculator, 1. model documentation, U.S. Department of Agriculture, Agricultural Research Service, Technical Bulletin 1768, 1990.

Shentis, I, Meirovich, L., Ben-Zvi, A., and Rosenthal, E.: Assessment of transmission losses and groundwater recharge from runoff events in a wadi under shortage of data on lateral inflow, Negev, Israel, Hydrol. Process., 13, 1649-1663, 1999.

Singh, V. P. and Woolhiser, D. A.: Mathematical Modeling of Watershed Hydrology, J. Hydrol. Eng., 7(4), 270-292, 2002.

Srinivasan, R. and Arnold, J. G.: Integration of a basin scale water quality model with GIS, Water Resour. Bull., 30(3), 453-462, 1994.

Srinivasan, R., Arnold, J. G, Rosenthal, W., and Muttiah, R. S.: Hydrologic Modeling of Texas Gulf basin using GIS, in: Proceedings of the 2nd International GIS and Environmental Modeling, Breckinridge, Colorado, September 1993, 213-217, 1993.

Taamallah, H.: Carte pédologique de la Jeffara, internal report, IRA/IRD, Tunis, Tunisia, 2003.

Walkley, A. and Black, I. A.: An examination of the Degtjareff method for determining soil organic matter and a proposed modification of the chromic acid titration method, Soil Sci., 37, 29-38, 1934.

Williams, J. R., Jones, C. A., and Dyke, P. T.: A modelling approach to determining the relationship between erosion and soil productivity, Transactions of the American Society of Agricultural Engineers, 27(1), 129-144, 1984.

Zerrim, A.: Cartographie de l'occupation du sol par l'usage des données de télédétection : Cas du bassin versant Oum Zessar. Graduation thesis, Ecole Supérieure des Ingénieurs de l’Equipement Rural, Mjez El Bab, Tunisia, 2004. 